\title{
Article
}

\section{"No Entry into New South Wales": COVID-19 and the Historic and Contemporary Trajectories of the Effects of Border Closures on an Australian Cross-Border Community}

Dirk H. R. Spennemann (D)

check for updates

Citation: Spennemann, D.H.R. "No Entry into New South Wales": COVID-19 and the Historic and Contemporary Trajectories of the Effects of Border Closures on an Australian Cross-Border Community. Land 2021, 10, 610. https://doi.org/ 10.3390/land10060610

Academic Editor:

Thomas Panagopoulos

Received: 20 April 2021

Accepted: 3 June 2021

Published: 7 June 2021

Publisher's Note: MDPI stays neutral with regard to jurisdictional claims in published maps and institutional affiliations.

Copyright: (C) 2021 by the author. Licensee MDPI, Basel, Switzerland. This article is an open access article distributed under the terms and conditions of the Creative Commons Attribution (CC BY) license (https:// creativecommons.org/licenses/by/ $4.0 /)$.
Institute for Land, Water and Society, Charles Sturt University, P.O. Box 789, Albury 2640, Australia; dspennemann@csu.edu.au

Abstract: Given its intensity, rapid spread, geographic reach and multiple waves of infections, the COVID-19 pandemic of 2020/21 became a major global disruptor with a truly cross-sectoral impact, surpassing even the 1918/19 influenza epidemic. Public health measures designed to contain the spread of the disease saw the cessation of international travel as well as the establishment of border closures between and within countries. The social and economic impact was considerable. This paper examines the effects of the public health measures of "ring-fencing" and of prolonged closures of the state border between New South Wales and Victoria (Australia), placing the events of 2020/21 into the context of the historic and contemporary trajectories of the border between the two states. It shows that while border closures as public-health measures had occurred in the past, their social and economic impact had been comparatively negligible due to low cross-border community integration. Concerted efforts since the mid-1970s have led to effective and close integration of employment and services, with over a quarter of the resident population of the two border towns commuting daily across the state lines. As a result, border closures and state-based lockdown directives caused significant social disruption and considerable economic cost to families and the community as a whole. One of the lessons of the 2020/21 pandemic will be to either re-evaluate the wisdom of a close social and economic integration of border communities, which would be a backwards step, or to future-proof these communities by developing strategies, effectively public health management plans, to avoid a repeat when the next pandemic strikes.

Keywords: geographic borders; urban geography; public health measures; contagious disease management

\section{Introduction}

Soon after its existence became public in late January 2020, COVID-19, the disease caused by the coronavirus SARS-CoV-2 [1], rapidly developed into a pandemic in the globally interconnected world of business and leisure travel [2]. At each national level, government reactions to curb or slow the progress of COVID-19 have involved the reduction of international arrivals to repatriation flights, limitations to domestic travel, limitations to crowd sizes, the temporary shut-down of non-essential businesses and the restriction of human movement during periods of "lockdown" (stay-at-home orders) [3-5]. In addition, in some jurisdictions, lockdown orders were applied at the sub-national level [6]. As the year 2020 progressed, many countries experienced a second and even a third wave of infections $[7,8]$ with recurrences of small clusters even where COVID-19 could be largely suppressed. At the time of paper acceptance (on 2 June 2021), 165.2 million people had been infected on all continents in all but seven countries, with a global death toll of 3.4 million [9]. The recurrence of COVID-19 infections led to a renewal of lockdown orders and movement restrictions, including border closures. There is only limited literature on the effects of border closures on the actual movement of people and the social and economic costs this caused. The impact has been profound, however, knowing that international movement of 
people had become increasingly free of restrictions, with many countries having bilateral agreements on visa-exempt travel.

Cross-border communication and integration flourished in Europe in the post-Cold War era [10]. Globalisation has seen an intermeshing and horizontal integration of national economies and trade, as exemplified by the proliferation of just-in-time supply chains and goods and food supplies. During the heyday of the globalisation movement, expressed in the plethora of free trade agreements and bi-lateral agreements on visa-exempt travel, physical national borders were on a trajectory to obsolescence. The European Union's Schengen agreement of 1985 is a case in point [11]. The free flow of goods and services, coupled with increased affordability of air travel, was poised to generate a seamlessly integrated world-at least for the developed countries [12]. Civil unrest in the Near and Middle East as well as Northern Africa, coupled with extreme economic inequalities in Sub-Saharan Africa and Central America, resulted in an increased movement of political, humanitarian and economic refugees [13]. Some countries responded with the reestablishment of some hard borders replete with barbed wire fencing $[14,15]$.

The COVID-19 pandemic acted as a major disruptor to globalization and borderless travel. The public health measures enacted as a response to the COVID-19 pandemic have entailed the reduction of privacy (via contact tracing registers) and limitations on the freedom of movement and assembly. Some authors have posited that a resurgence of enforceable borders may become the "new normal" [16]. Setting aside the actions to prevent the arrival and initial seeding of the disease in a country $[17,18]$, many countries imposed domestic and cross-border travel restrictions to prevent new strains from arriving, or to maintain a disease-free state in cases where suppression had been effected (e.g., Australia and New Zealand) [19].

Movement restrictions were not only imposed on international travel, but also on movement within a given country, breaking the tenet of unfettered freedom of movement and choice of abode that had been a civil right for many generations. To combat the spread of COVID-19, many countries resorted to tried-and-true personal movement control and limitation measures, such as ring-fencing $[20,21]$ and border closures (this paper). While ring-fencing within states may encounter practical problems of compliance and policing [22], border closures are more effective as natural or anthropogenic barriers may inhibit population movement. Suddenly, borders became en vogue again.

In the Australian setting, the country experienced a full national lockdown between 31 March and mid-May 2020 [23], with a subsequent gradual easing of restrictions. Repeated localised outbreaks led to the imposition of temporary lockdown provisions in numerous states, which resulted in restrictions to assembly and movement, including cross-border traffic. The post-World War II generations of Australians had always enjoyed a high percentage of car ownership and the freedom of movement that entailed [24]. Moreover, the country, spanning four major environmental zones from the equatorial tropics to cool temperate [25], had become reliant on interstate commerce of food, goods and services $[26,27]$. While some residents were aware of differences between the states (e.g., differences in road rules or high school leaving certificates), these differences rarely impacted on the personal lives of the majority. Suddenly that would come to an end, with the COVID-19 pandemic starkly exposing the realities of the states imposing their own, different public health measures.

Using the cross-border community of Albury (New South Wales, Australia) and Wodonga (Victoria) as a case in point, this paper will focus on the social and community impacts of the public health measures of "ring-fencing"[22] and the prolonged 2020 and the shorter 2021 closure of the state border between New South Wales and Victoria. It will place the events of 2020/21 into the context of the historic and contemporary trajectories of the border between the colonies (later states), focussing on the impact of the border on inter-community communications and commerce. It will show that while closures of colonial/state borders had been employed as public-health measures in the past, their social and economic impact had been negligible at the time due to low cross-border community 
integration. Concerted efforts (since the mid-1970s) to forge a true cross-border community have led to the effective and close integration of employment and services in the AlburyWodonga region, which were significantly impacted when the state border was suddenly and unilaterally closed as part of COVID-19 public health measures.

\section{Materials and Methods}

This paper employs a mixed methods methodology, encompassing standard historic research, historic and current statistics, document analysis and lived experience. The historic information was sourced from contemporary regional and metropolitan newspapers digitized by the National Library of Australia [28] and legislation and regulations as promulgated by colonial and (later) state governments; historic and current statistical data were obtained from published census publications as well as data sets provided by the Australian Bureau of Statistics; press releases and other government publications provided the context of the management of the COVID-19 pandemic. The discussion of the impact of the border closure during the COVID-19 pandemic is augmented by lived experience observations, both personal and by fellow residents, by virtue of the author living in the border area under discussion. Where required, these are identified as "pers.obs".

The study area is Albury-Wodonga, a cross-border community of 96,000 people, and a number of smaller satellite communities, located in south-eastern Australia (Figure 1).

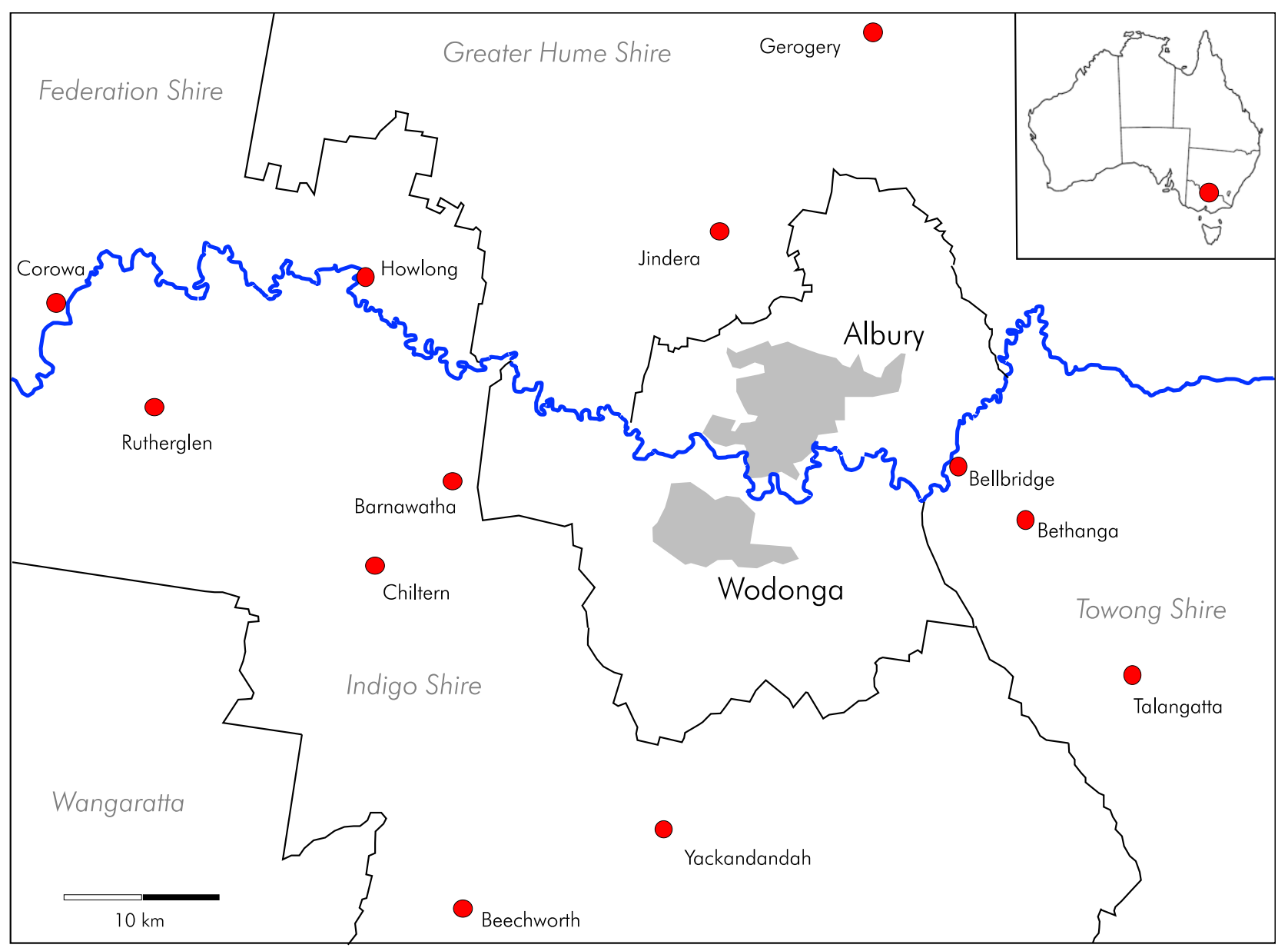

Figure 1. Map of Albury-Wodonga and surrounds, showing the local government area boundaries and locations mentioned in the text. Inset: location of Albury-Wodonga in relation to Australia.

Given that this paper provides a conceptual discussion of the subject matter, rather than an experimental design, the structure of the paper deviates from the standard IMRAD format and presents discusses the subject matter in the form of contextual narrative. The 
on occasion detailed description of the historic trajectory lays the groundwork for an understanding of the present social and economic condition of the study area. A section on preconditions describes the nature of the border area prior to the establishment of European borders and shows that the Murray River was a liminal zone rather than an administrative and later political border. These are discussed by describing the creation of separate political entities with customs points, the subsequent removal of these following Australia's Federation and the concerted efforts to merge two cross-border towns into an integrated social, cultural and economic community. This contextualises the discussion of the nature and impact of the imposition the border closures on the local community. The discussion of the historic trajectories demonstrates why the impacts of the border closures during the COVID-19 pandemic had greater effects on the cross-border community than previously.

\section{Preconditions}

It appears that prior to the European invasion, the Murray River was not a border, but a liminal zone for Indigenous Australian groups that had their centre of gravity in adjacent areas. Thus, in the Albury-Wodonga area, the Waveroo (Minubuddong) were reputed to have accessed both banks of the Murray [29] as were the Wiradjuri [30,31]. Fords were essential locations that facilitated and maintained cross-river communication.

The arrival of European settlers invading Indigenous Australian lands along the Murray commenced soon after the traverse by Hume and Hovell in 1824 [32]. At the same time as European colonisation expanded, increasingly marginalising and displacing the Indigenous communities as owners of the land [33], European settlers acquired and utilised Indigenous knowledge of the river and fords suitable for crossing. In the Albury-Wodonga region, the initial alienation from Indigenous ownership occurred in 1835, with the creation of the Mungabareena and Bonegilla Runs [34-36] and the erection of a store at the location at a long-established river crossing at the confluence of Bungambrawatha Creek with the Murray [37,38]. That crossing was chosen in favour of nearby crossings which were less suitable topographically ("Yarrawudda") or politically ("Mungabareena"), with the latter being next to the permanent Wiradjuri settlement site [33]. In consequence, the township of Albury was formally laid out adjacent to the Bungambrawatha crossing in 1839 [36,39].

For Europeans, the Murray did not form a liminal zone but a barrier that had to be overcome, usually by the establishment of punts followed by bridges. The universal pattern of 19th century crossing points is that of a main community on one side of the river and a small bridgehead community on the other (Table 1). The productivity of the surrounding hinterland and subsequent flow of goods and communications defined which of the paired communities would become the larger of the two, even in cases where the other was founded first.

Table 1. River crossings and paired communities along the Murray. The larger community is shown in capital letters.

\begin{tabular}{ccccc}
\hline New South Wales & Victoria & Punt & Bridge & Source \\
\hline ALBURY & Wodonga ("Belvoir”) & 1844 & 1860 & [36] \\
HOWLONG & † Gooramadda & $<1862$ & 1908 & 1862 \\
COROWA & Wahgunyah & $1857 / 8$ & 1891 \\
Mulwala & YARRAWONGA & 1850 & 1904 \\
Barooga & COBRAM & 1889 & 1895 \\
TOCUMWAL & - & 1872 & 1876 \\
Moama & ECHUCA & 1850 & 1905 \\
BARHAM & Koondrok & 1884 & 1927 \\
\hline
\end{tabular}

† No longer a formal community in existence.

Albury continued to expand as a rural service centre with all produce being shipped to Sydney and all goods obtained from there $[36,41]$. Wodonga, initially surveyed as 
"Belvoir" in 1852 and renamed to "Wodonga" in 1874 [42,43], gradually developed from a single pub/hotel location into a bridgehead town extending along the Sydney-Melbourne road [44]. The first formal option to cross the Murray rather than to use the ford was a privately-owned punt that operated on the Albury side from 1844 onwards. This was replaced by a government-owned ferry in 1849 and then by a formal bridge in 1861 [36]. The bridge, combined with the creation of a formed roadway across the Murray floodplain, ensured safe and reliable crossing in all but situations of extreme spring floods when the floodplain might be impassable for heavy wagons. Just before the bridge had been opened to overcome the physical barrier represented by the river, however, a new political barrier had been created.

\section{Emergence of the State Border}

Coming from Tasmania, European pastoralists invaded the south coast of Victoria and settled in Portland Bay (1834) and Port Philip Bay (1835), eventually establishing settler communities that gradually, but systematically colonised the surrounding areas to the Great Dividing Range, displacing traditional Indigenous owners in the process $[45,46]$. Despite attempts by the colonial government to prevent the establishment of a colony, a fait accompli was created with the surveying of the township of Melbourne (1837) and the establishment of a semi-autonomous colony in 1839 [46], which led to the formal formation of the separate colony of Victoria in July 1851 [47].

Deeply steeped in British administrative traditions of survey and land partitioning, the lands offices in Sydney and Melbourne had long been using waterways as natural, and thus easily definable, boundaries that could also be readily identified in the landscape [48]. Thus it is not surprising that the Murray River conveniently running from the east to west was declared to be the border between the two colonies. Only in the Australian Alps, a land border had to be defined, using an arbitrary line from Cape Howe on Australia's east coast to the most eastward approach of the Murray River [49,50]. Given that the river was a resource in terms of navigation, fish and potentially power generation (with water wheels driving flour- and sawmills), New South Wales retained the rights to the river and ensured that the colonial boundary was formed by the southern bank of the river [51]. Albury and Wodonga had become border towns.

In 1852 both New South Wales [52] and Victoria enacted customs legislation, but it was not until three years later that inter-colonial regulations focussing on the Murray River trade were introduced. The introduction of the Customs Act in 1855 (NSW) [53] and the Murray Customs Duties Act of the same year (Victoria) [54], caused a dramatic decline in inter-colonial commerce on which Albury depended [55]. The lifting of the customs duties in December 1855 was short-lived [56], as they were reintroduced in 1860 [57]. What followed was a sequence of lifting and reintroduction of customs duties [58,59] that confused and annoyed border residents [60]. The customs duties were finally abolished with the Federation of the Australian colonies on 1 January 1901 [61].

To allow for the intensification of agricultural production and reduce the costs of transportation, while at the time directing the trade to their own metropolitan centres rather than, literally, down the river to Adelaide [62], both Victoria and New South Wales developed hub-and-spoke railways systems, centred on their respective capital cities [63-65]. One of the quirks of the colonial period, however, was that both colonies were adamant that their railway gauge was preferable, with the inevitable result that when the railway lines finally met at the Murray, neither train could progress beyond the termini in Wodonga (1872) and Albury (1881). Even though the Victorian line was extended from Wodonga to Albury in 1883, the break in the gauge required the transfer of all goods and passengers from one train to the other, until rectified in 1963 when the NSW gauge was extended to Melbourne [66,67]. 


\subsection{Effects of Federation}

When the Commonwealth of Australia eventuated in 1901, the primary effect, on a domestic level, was the uninhibited movement of people and goods across colonial (and henceforth state) borders [68,69], even though the practical implementation did not occur until 1913 [61]. While the Federation created a single country, the powers of the new nation were restricted to those that the former colonies were happy to surrender to as a central government (e.g., foreign affairs, defence, racial legislation). Critically, the colonies retained all powers associated with land management (incl. agriculture), natural resources, education and health. Colonial concepts and rivalries (as exemplified by the railway gauge) were readily ported to state realities. Even today, 120 years since the Federation, state rivalry still persists, resulting in a dissonance of legislative, regulative and administrative approaches [70].

While the Murray River represents the formal border between New South Wales and Victoria, and thus forms the boundary of different land laws, planning rules and health regulations, it is not an absolute breakpoint. Alternative borders did, and still do, exist. At the Federation, Australia had been divided into military districts, with Military District 3 encompassing Victoria. In 1911 that district was enlarged, now taking in some of the border communities north of the Murray, such as Corowa, Moama and Mulwala (44th Battalion area), while Wodonga, Barnawartha, Chiltern and Tallangatta (57th Battalion area) south of the Murray formed part of District 2 centred on Sydney [71]. A reorganisation of the districts in 1939 extended the Military District 3 to encompass the Southern Riverina to the Murrumbidgee (but not including Wagga Wagga) [72].

There is an additional, "cultural" divide with a broadly similar boundary: the "Barassi Line". Victoria, as well as the border region along the Murray River, primarily follow the sporting code of Australian Rules Football, while the rest of New South Wales, from about Wagga Wagga northwards, follows Rugby Union and Rugby League [73]. Similarly, differences in the quality of roads and the density of the road network meant that much of the produce of the southern Riverina east of Corowa went to Melbourne, rather than Sydney [67].

\subsection{Albury-Wodonga}

The effects of the Federation on Albury-Wodonga were primarily the removal of customs duties, making the interstate exchange of goods cheaper. Albury continued to develop as a major rural service centre, in part driven by its access to both railway gauges. Wodonga continued as a bridge-head community.

The fluidity of the borders in the post-Federation era was an important element in 20th-century Australia. Lived experience in the Albury-Wodonga over the past 30 years can attest that, until the COVID-19-induced border closures (see below), the border was irrelevant in people's daily lives, manifesting itself largely in quirks like car registration being more expensive in New South Wales and Victoria having slightly different traffic rules, such as permitting U-turns at traffic lights.

\section{19th and 20th Century Border Closures}

Even though during colonial times the border was open for traffic and goods transfer, albeit subject to customs duties, the border was not always open for commerce and communications. In fact, there were a number of unilaterally decreed closures. The same occurred in the period after the Federation, when trade and movement of people were supposedly wholly unrestricted.

\subsection{Border Closures during Colonial Times}

Following the outbreak of pleuro-pneumonia in Victoria, New South Wales restricted all cattle imports across the Murray from August 1861, leading to a full border closure in early November until early $1862[74,75]$. The manifestation of the disease in Albury in late November 1861 caused a reverse, with Victoria closing its border along a stretch of the river 
from Cudgewa Creek to a point 10 miles downstream of Wahgunyah, with pounds for animal quarantine set up at the crossing points (bridges) at Albury and Wahgunyah [76]. Given that all heavy goods transport at the time relied on bullock teams, and bullock teams had been implicated in the spread of the disease [77,78], all cross-border transport of wool, wine and grain was effectively curtailed, severely affecting the economy of border towns and the adjacent rural communities. At the end of the same decade, New South Wales closed its border to Victorian sheep from March to May 1869 due to an outbreak of scab $[79,80]$.

\subsection{Post-Federation Border Closures}

While after the Federation people and goods could, at least in theory, move freely between states, public health and agricultural issues soon emerged, which had remained under the control of the states. Some of these concerns resulted in travel restrictions and inspections of travellers and vehicles. In 1904, for example, New South Wales sheep from selected areas were prevented from entering Victoria for fear of anthrax [81], while in the following year Victorian fruit was inspected for fruit flies on import to New South Wales.

The first major border closure occurred during the pneumonic influenza pandemic of 1918-19 ("Spanish flu") which cost between 17.4 and 50 million lives globally [82]. Once pneumonic influenza was detected in Victoria, New South Wales unilaterally closed its borders on 20 January 1919. A buffer of 10 miles was established on either side of the border that allowed residents to cross, provided that they were disease-free and had quarantined for seven days (later four days) in a non-affected area within the zone [83,84]. Although not intended [85], the border closure interrupted the flow of goods and mails between many border communities [86]. It did not prevent the disease from crossing state boundaries $[87,88]$, however, since local knowledge of unpoliced crossings allowed the restrictions "being evaded at many points" [89,90]. These movement restrictions disrupted many cross-border social linkages, in particular during the initial period.

While the majority of the newspaper coverage comments on the impact of the closures on the interstate traffic in goods and people, there is ample evidence that it also impacted the cross-border community of Albury-Wodonga at a local level. Newspapers commented on "marooned people from this State [NSW, ed.] who are anxious to return home. The hotels and private houses of Wodonga are filled with those people" [85] and noted that "many Wodonga people who work in Albury have been unable to reach their business place. Others have had to seek accommodation in Albury" [91].

In early March 1919, the influenza pandemic had firmly established itself in New South Wales, obviating the need for border closures. Upon entry, however, Victorian residents still had to produce a medical certificate vouching that they were influenza-free [92]. Indeed, the border closures during the 1919 influenza pandemic saw an inconsistent approach to policing, with some bridges policed systematically, while the river often remained unpatrolled at less well-established crossings. To allow through-traffic by trains, travellers had to submit (at their cost) to medical examinations in Sydney and at arrival in Melbourne. Enterprising individuals circumvented this by booking the train to Albury, crossing the border by taxi to Wodonga, where they booked a seat on the train to Melbourne [93,94]. In response, Quarantine officers were placed at the Albury bridge at random intervals. People wishing to avoid quarantine detention resorted to crossing the bridges when not staffed, using less frequented crossings or even swimming the river $[89,90,95,96]$. The police responded by increasing their presence which included patrolling the river by boat $[95,96]$. Many of those who crossed illegally were eventually tracked down and placed in quarantine [97].

Other closures were more selective and specific. The rapid development of heavy road transport in the 1930s, hauling goods interstate, posed a threat to the viability of state-owned railways. Consequently, New South Wales (in 1931) and Victoria (in 1935) imposed restrictions on interstate road traffic, until Privy Council in London declared this unconstitutional in 1947 [98,99]. 
Unlike the politically motivated border closures to long-haul heavy goods traffic, the other border controls were motivated by public and agricultural health.

Between August 1937 and April 1938, when News South Wales prevented Victorian children under the age of 16 from entering unless they could produce a medical certificate vouching that they had not been exposed to a contact suffering from infantile paralysis (poliomyelitis). Special constables were commissioned to police this at all border crossings from Victoria [100]. Finally, to combat the fruit fly, in June 1959 Victoria prohibited the import of a range of fruits into the state and instituted checks on imported fruit at border crossings [101]. In the Albury-Wodonga area, inspection stations were established at the Albury railway station (for goods shipped by rail) and on Causeway Island (on the floodplain) to inspect all road traffic. To emphasise the scientific need for this disruption of the cross-border traffic, fruit fly inspectors staffing the road blocks carried note boards and wore white laboratory coats (Figure 2) [102]. This practice was discontinued and replaced by mobile spot checks in 1980 [103].

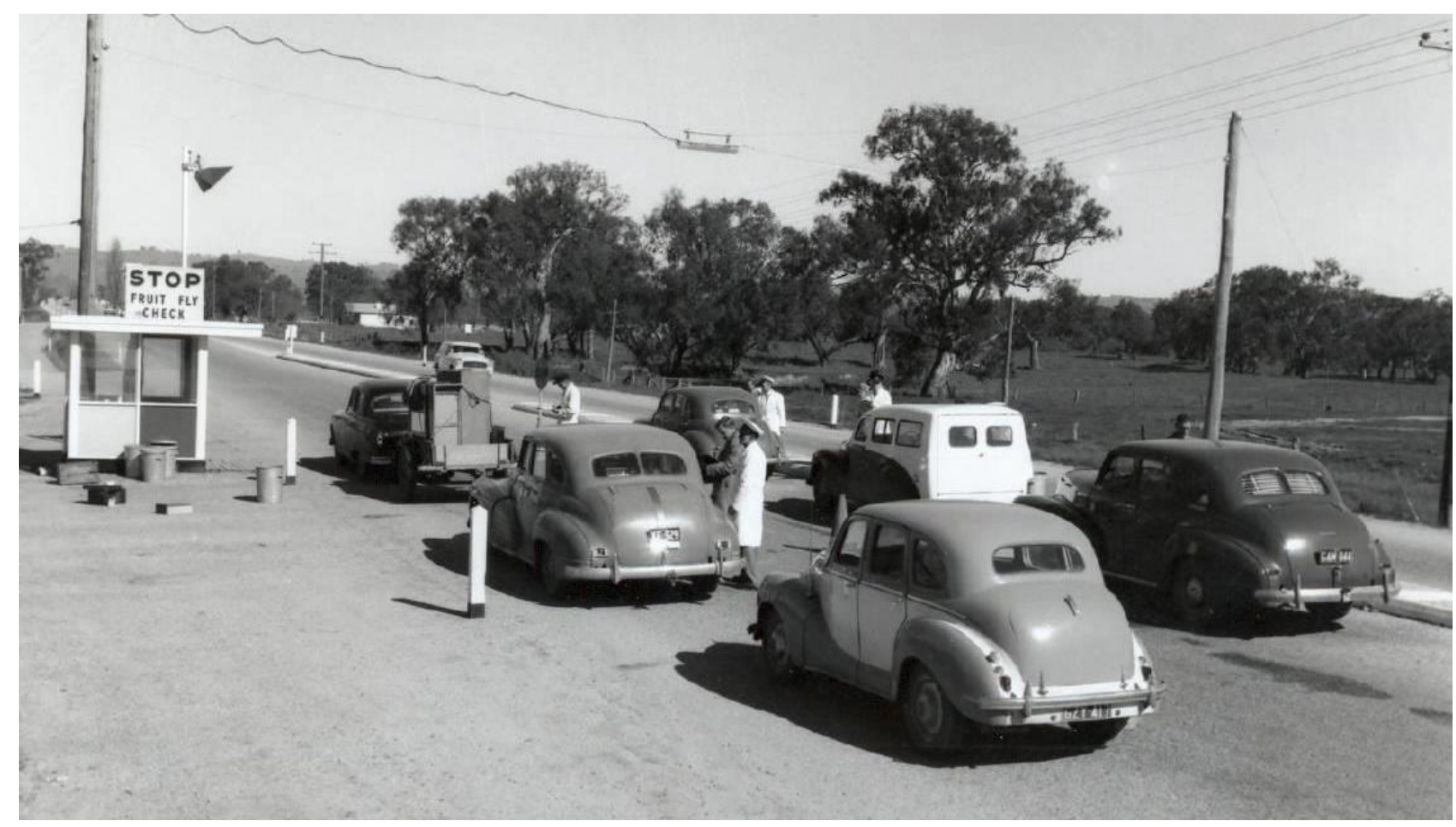

Figure 2. Fruit fly checkpoint on the Lincoln Causeway, August 1961 (Image: Wodonga Historical Society).

\section{Decentralisation}

While Indigenous Australia prior to the European invasion had essentially been a decentralised and distributed occupation, colonial and later Federal Australia had always been centralised. Some resource extraction and industrial centres (e.g., Ballarat, Bendigo, Lithgow, Port Kembla) notwithstanding, the European population focussed on the mercantile and small-industrial capacity and the resulting employment opportunities in the respective capital cities. The common denominator of the period until the early 1970s is that while cross-border commerce, as well as cross-border social contact existed, the level of integration of the cross-border communities remained limited. In all paired communities, one community was significantly larger, while the other continued to function, in essence, as a bridgehead. Albury-Wodonga was no different, as evidenced by the overall population figures (Table 2). Changes to communications infrastructure (the bridge in 1861) and political arrangements (Federation in 1901) are well reflected in the changes to the relative proportion of the two communities, followed by periods of proportional stability (Figure 3). An effective plateau of Wodonga's population, being about one-third of that of 
Albury's, was reached after World War I and remained stable for 50 years. That changed when the Whitlam Labour government was elected to power in 1972. Now, the Commonwealth government embarked on an ambitious program of decentralisation, planning the establishment of a number of regional growth centres in the wheat-sheep belt of SE Australia, with state and federal governments providing financial incentives for companies to relocate production there [104-106]. One of these was Albury-Wodonga, which was formally announced on 25 January 1973. Planning and execution were handed to the Albury-Wodonga Development Corporation (AWDC), which was given wide-ranging planning powers to acquire and subdivide land in order to develop both Albury and Wodonga. This led, inter alia, to the Greenfields communities of Thurgoona (Albury) and Baranduda (Wodonga), both of which have since then become nuclei for further expansion. While the national growth centre strategy was abandoned with the change of government at the next election [104], the ADWC continued, albeit less well funded and later (in 1992) it was disembowelled by the removal of planning powers, as a land management agency until its formal wind-down in 2003 [104].

Table 2. Population growth of Albury and Wodonga.

\begin{tabular}{cccccccc}
\hline Year & Albury & Wodonga & Source & Year & Albury & Wodonga & Source \\
\hline 1835 & & & & 1954 & 16,736 & 5260 & {$[105,107]$} \\
1846 & 65 & & {$[108]$} & 1961 & 18,621 & 7501 & {$[108,109]$} \\
1851 & 442 & & {$[108]$} & 1966 & 25,112 & 8653 & {$[105,108]$} \\
1854 & & 34 & {$[44]$} & 1971 & 28,420 & 10,530 & {$[105,108]$} \\
1856 & 645 & & {$[108]$} & 1976 & 32,944 & 15,733 & {$[110]$} \\
1861 & 1587 & 254 & {$[108,111]$} & 1981 & 37,350 & 19,540 & {$[105]$} \\
1871 & 2592 & 359 & {$[108,112]$} & 1991 & 39,190 & 23,160 & {$[105]$} \\
1881 & 5715 & 788 & {$[108,113]$} & 1996 & 42,322 & 30,200 & {$[110]$} \\
1891 & 5447 & 891 & {$[108,114]$} & 2001 & 42,314 & 30,921 & {$[115,116]$} \\
1901 & 5821 & 941 & {$[108]$} & 2006 & 46,282 & 33,010 & {$[117,118]$} \\
1911 & 6309 & 1510 & {$[110,119]$} & 2011 & 47,810 & 35,519 & {$[120,121]$} \\
1921 & 7751 & 2553 & {$[108,122]$} & 2016 & 51,076 & 39,351 & {$[123,124]$} \\
1933 & 10,543 & 3250 & {$[110]$} & 2021 & 54,353 & 42,083 & Estimates \\
1947 & 14,412 & 4273 & {$[108,125]$} & & & & \\
\hline
\end{tabular}

While the AWDC could embark on a unified planning strategy, it remained hamstrung by the vast range of administrative and jurisdictional anomalies created by differences in New South Wales and Victorian state legislation $[105,126]$. The lack of a national approach, coupled with the return of planning powers to the local councils in 1992, saw the resurgence of parochial interests, with both Albury and Wodonga competing with each other for businesses and residents [104,105].

In the 1980s and 1990s, the combined rural service centre of Albury-Wodonga began to feel the impact of the decline of the railways and the rise of road transport. A number of its large wool stores were forced to close, such as Younghusband's (1986), Farmers and Graziers Wool Store (1997) and Dalgety's (2002). The flour mill closed in 2008 and the paper mill (founded in 1983) closed in 2019. Increased globalisation and competition from countries with cheaper labour saw a decline in production, resulting in the closure of Macquarie Textiles in 2013 [127], while the DSI automotive transmission plant (founded as Borg-Warner in 1970 facilitated by industry incentives) [128] was closed in 2014 when its Chinese owners repatriated the IP [129].

While the economic impact on the communities forced the realisation that Albury and Wodonga should collaborate rather than compete, parochialism and individualism abounded. Even though the two councils made a number of attempts at collaboration, as documented in various Memoranda of Understanding between 1998 and 2017 [130-132], the real drivers for integration were the State governments who had the power to overcome the vast range of border anomalies [126]. While the 2001 push by the State governments to create a National City failed, largely due to intransigence by one of the local coun- 
cils [105], integration occurred on a gradual, yet systematic level. Over the past decade, the health systems, in particular, have become closely integrated with all obstetrics, for example, in Wodonga and all oncology in Albury [133,134]. A multi-governmental level agreement on further integration and cross-border planning and regulatory harmonisation was announced in mid-2020 [135].

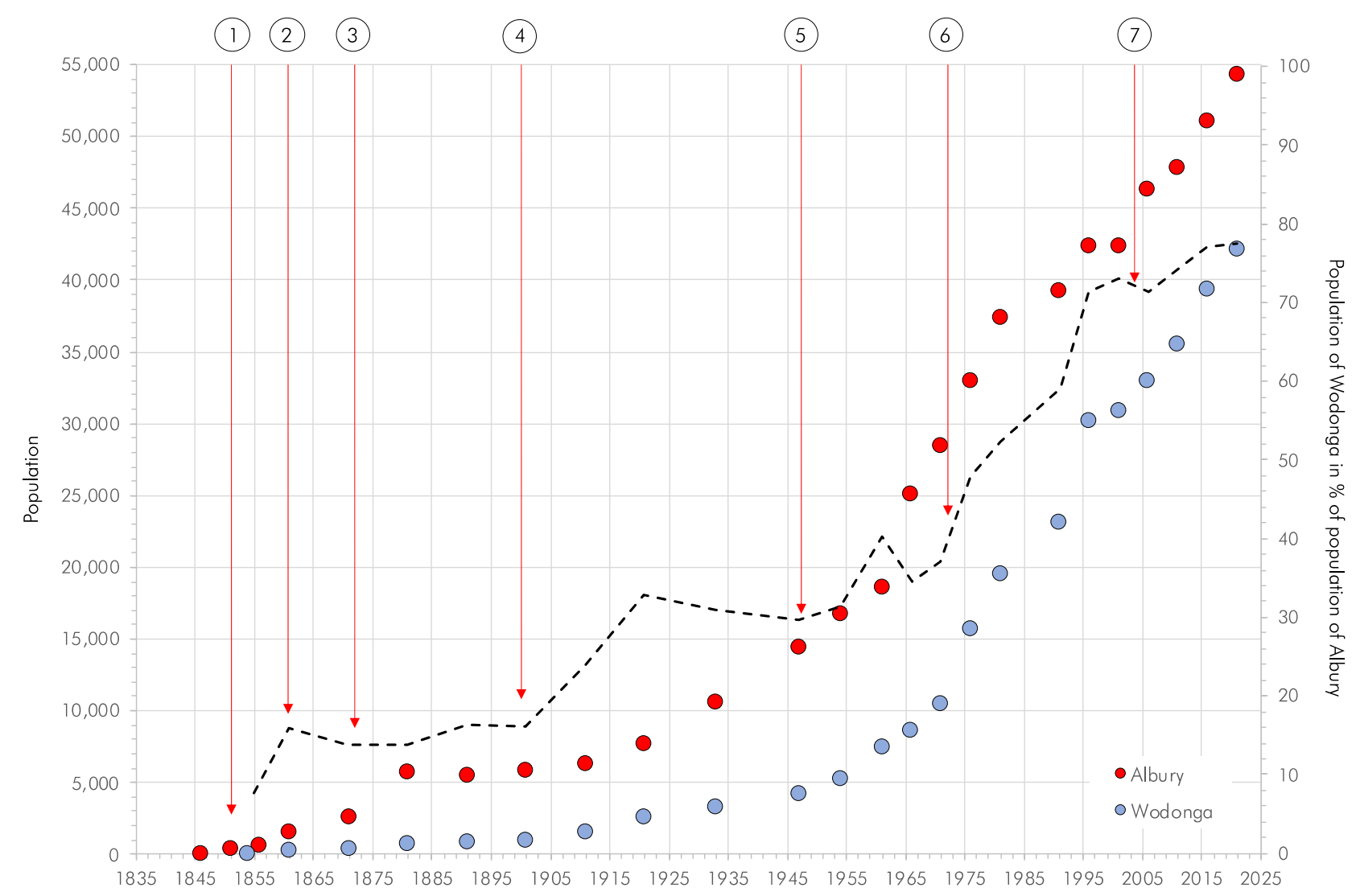

Figure 3. Development of the population of Albury and Wodonga with significant events marked (for data see Table 2). The dashed line shows the population of Wodonga in percent of the population of Albury. Events: 1-formation of the Colony of Victoria; 2 - opening of the bridge across the Murray; 3-Victorian railway reaches Wodonga; 4-Federation; 5-Bonegilla Migrant Centre opens; 6-Albury-Wodonga Development Corporation formed; 7-Albury-Wodonga Development Corporation ceases.

In the 1990s and early 2000s, the desire for an affordable lifestyle and rural accommodation saw the growth of dormitory towns that ring Albury-Wodonga: Chiltern, Howlong, Gerogery and Jindera in New South Wales and Barnawartha, Beechworth, Bellbridge, Bethanga, Tallangatta and Yackandandah in Victorias, with Rutherglen (Vic) and Corowa (NSW) a bit further afield (Figure 1) [136].

The effects of this integration are well reflected in the relative proportion of the resident population. While the population of both communities increased continually (Table 2), centralised planning caused the population imbalance to gradually even out: in 1971 the population of Wodonga was 37\% of that of Albury, while in 2021 it was at $77.4 \%$ (Figure 3). Both Albury and Wodonga have become communities with a high level of intercensal migration primarily to and from other locations in Australia (Table 3). This has increased significantly since the mid-1970s. Compared to the overall population growth of the two communities, the growth of the permanent, non-migrating population has been much slower. Inter-community relocation of a primary residence between Albury and Wodonga is very small (2.3-3.1\% of the non-migrating population), with an intercensal net gain for Wodonga of between 20 and 30 persons per year (Table 4, Figure 4). Today, Albury and Wodonga are a community with shared facilities and economy with large 
numbers of people living and working on different sides of the border. The proportion of Albury-Wodonga citizens residing in one but working in the other town has increased from $19.8 \%$ in the 2006 census to $22.7 \%$ in the 2016 census (Table 5). Including the adjacent communities, the total of the cross-border movement now involves about a quarter of the workforce. This figure does not include high school and university students who may reside in one town and study in the other, nor does it include casual border crossings, for example, to access medical facilities.

Table 3. Changes in residential addresses (\%) in intercensal periods for Albury and Wodonga.

\begin{tabular}{cccccc}
\hline \multirow{2}{*}{ Census } & \multicolumn{3}{c}{ Usual Address Five Years Prior } & \multirow{2}{*}{ Total } \\
\cline { 3 - 5 } & & No Change & Other Australia & Overseas & \\
\hline \multirow{3}{*}{ Albury } & 1976 & 73.99 & 23.36 & 2.65 & 33,451 \\
& 2006 & 58.14 & 40.27 & 1.58 & 38,275 \\
& 2011 & 57.49 & 39.57 & 2.93 & 42,092 \\
Wodonga & 2016 & 55.74 & 41.79 & 2.48 & 43,907 \\
& 1976 & 60.07 & 37.89 & 2.04 & 15,905 \\
& 2006 & 54.27 & 44.13 & 2.04 & 27,618 \\
& 2011 & 53.93 & 44.03 & 1.86 & 31,378 \\
& 2016 & 52.99 & 45.15 & 33,866 \\
\hline
\end{tabular}

Data sources: AWDC 1978; Census of Population and Housing, 2006, 2011, 2016, Persons, Place of Usual Residence TableBuilder.

Table 4. Relocation of residences between Albury and Wodonga in absolute numbers and in percent of the total population.

\begin{tabular}{cccccc}
\hline \multirow{2}{*}{ Intercensal Period } & \multicolumn{2}{c}{ Albury $>$ Wodonga } & \multicolumn{2}{c}{ Wodonga $>$ Albury } & Net Gain Wodonga \\
\cline { 2 - 6 } & $\mathbf{n}$ & $\mathbf{\%}$ & $\mathbf{n}$ & $\mathbf{\%}$ & $\mathbf{1 3 0}$ \\
\hline $2001-2006$ & 940 & 2.5 & 810 & 2.9 & 130 \\
$2006-2011$ & 968 & 2.3 & 845 & 2.7 & 123 \\
$2011-2016$ & 1172 & 2.7 & 1051 & 3.1 & 121 \\
\hline
\end{tabular}

Data sources: Census of Population and Housing, 2006, 2011, 2016, Persons, Place of Usual Residence TableBuilder.

Table 5. Relationship of the place of residence with the place of work (in percent of residents in employment) for the census years 2006, 2011 and 2016 (Source Census of Population and Housing, 2006, 2011, 2016, Table Builder).

\begin{tabular}{|c|c|c|c|c|c|c|c|c|}
\hline & \multirow{2}{*}{2006} & \multicolumn{6}{|c|}{ Place of Residence } & \multirow{2}{*}{$n$} \\
\hline & & Albury & Corowa & Gr. Hume & Indigo & Towong & Wodonga & \\
\hline \multirow{8}{*}{ Place of Work } & Albury & 70.19 & 1.49 & 4.90 & 3.71 & 1.41 & 17.95 & 21,411 \\
\hline & Corowa & 3.31 & 79.87 & 3.10 & 11.79 & - & 1.93 & 3418 \\
\hline & Greater Hume & 9.97 & 2.93 & 84.20 & 0.88 & 0.67 & 1.35 & 2969 \\
\hline & Indigo & 4.13 & 10.19 & 0.30 & 73.42 & 0.70 & 9.21 & 4289 \\
\hline & Towong & 1.59 & - & 0.53 & 3.07 & 91.43 & 3.07 & 1891 \\
\hline & Wodonga & 22.46 & 1.33 & 1.65 & 8.78 & 1.95 & 63.04 & 15,508 \\
\hline & \multirow{2}{*}{2011} & \multicolumn{6}{|c|}{ Place of Residence } & n \\
\hline & & Albury & Corowa & Gr. Hume & Indigo & Towong & Wodonga & $n$ \\
\hline \multirow{8}{*}{ Place of Work } & Albury & 68.82 & 1.49 & 4.97 & 3.78 & 1.36 & 19.10 & 20,926 \\
\hline & Corowa & 4.25 & 78.51 & 1.28 & 13.91 & - & 2.20 & 3365 \\
\hline & Greater Hume & 13.95 & 0.93 & 81.56 & 0.63 & 0.59 & 2.35 & 3026 \\
\hline & Indigo & 4.46 & 9.13 & 0.33 & 74.21 & 0.97 & 8.63 & 4218 \\
\hline & Towong & 2.47 & - & 0.27 & 4.09 & 88.97 & 4.09 & 1859 \\
\hline & Wodonga & 25.08 & 1.54 & 1.72 & 8.61 & 1.97 & 60.25 & 15,548 \\
\hline & \multirow{2}{*}{2016} & \multicolumn{6}{|c|}{ Place of Residence } & 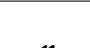 \\
\hline & & Albury & Federation & Gr. Hume & Indigo & Towong & Wodonga & $n$ \\
\hline \multirow{6}{*}{ Place of Work } & Albury & 66.08 & 1.64 & 5.06 & 4.20 & 1.43 & 21.04 & 24,059 \\
\hline & Federation & 5.25 & 76.03 & 1.78 & 13.77 & - & 2.93 & 3922 \\
\hline & Greater Hume & 15.77 & 1.60 & 79.21 & 0.22 & 0.26 & 3.01 & 3127 \\
\hline & Indigo & 4.92 & 8.08 & 0.43 & 72.22 & 1.14 & 10.77 & 4392 \\
\hline & Towong & 3.09 & - & 0.21 & 4.22 & 86.36 & 5.25 & 1943 \\
\hline & Wodonga & 24.92 & 1.53 & 1.76 & 8.14 & 1.87 & 60.94 & 18,111 \\
\hline
\end{tabular}




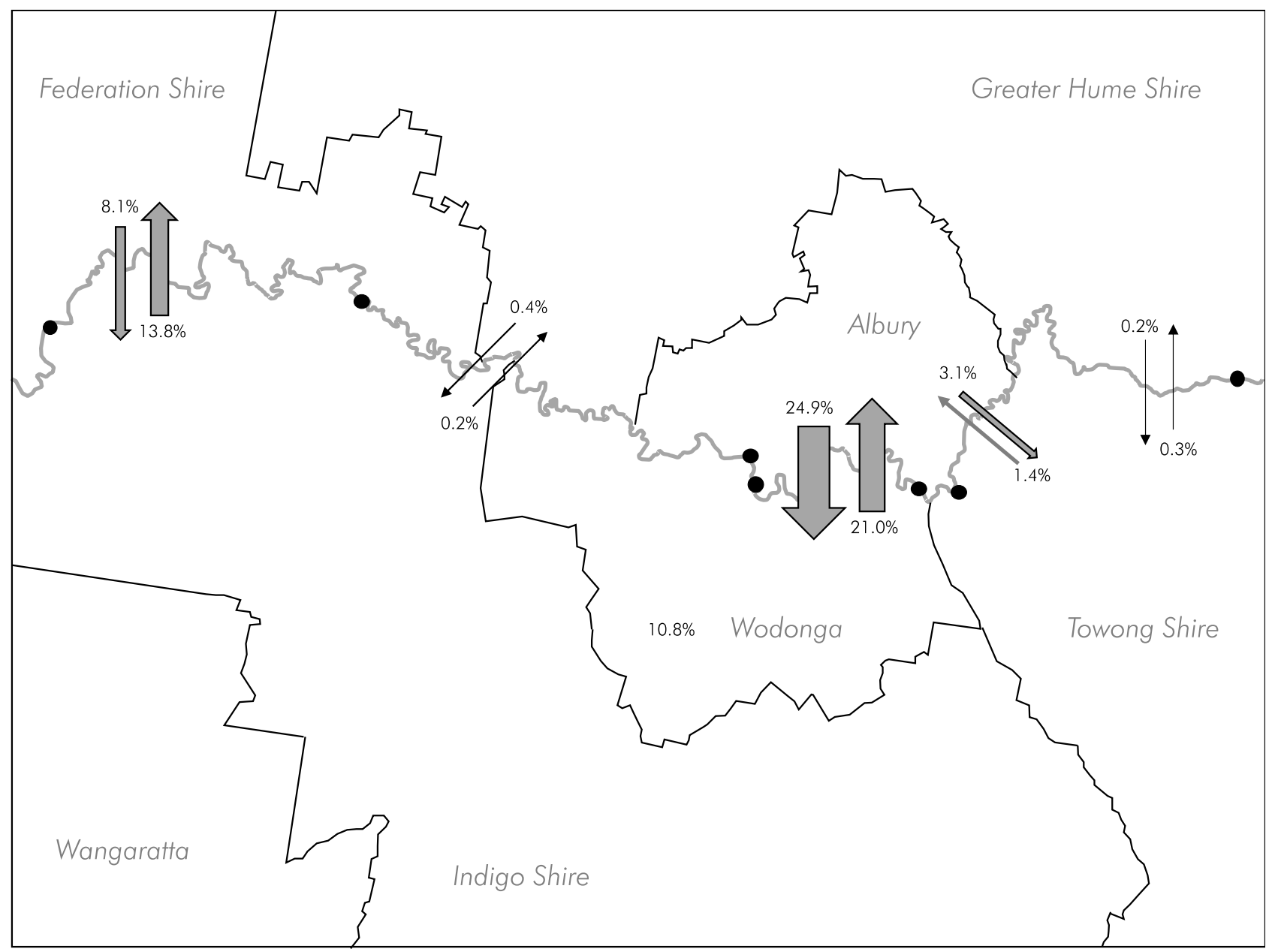

Figure 4. Cross-border commuting in 2016 in percent of residents in employment in a given local government area. The black circles indicate the location of river crossings for pedestrian or vehicular use. See Table 3 for data.

\section{Effects of Border Closures during the COVID-19 Epidemic}

While the extensive level of cross-border integration of facilities and services, as well as cross-border commuting, fulfilled the political aims of the two states, it became a liability with the emergence of the COVID-19 pandemic. Following a series of increasingly restrictive measures, NSW and Victoria went into a stage 3 lockdown on 31 March 2020 which lasted until mid-May 2020 [137-142]. That lockdown did not reveal the issues as both communities were equally affected. Following the escape of COVID-19 from Melbourne hotels housing overseas returnees in quarantine in late June 2020, and seeding in the community, the NSW state government unilaterally declared that the state border between NSW and Victoria be closed on 8 July 2020 [143]. Suddenly, almost a quarter of the workforce could no longer reach their place of work. This impact was compounded by the inability to shop across the border, which disproportionately affected Albury as the town has a greater range of specialty shops. Some smaller dormitory communities, such as Bellbridge and Bethanga (Figure 1), for example, are located in Victoria, but for all their goods and services, including fuel, rely on unfettered access to either Albury or Wodonga. With the firm border closures in place, the trip to Wodonga required a $59 \mathrm{~km}$ detour, extending the travel time by $50 \mathrm{~min}$.

Not surprisingly, the practicalities of enforcing the original Border Control Order [143] and the implications of that enforcement on the communities brought about a flurry of modifications, primarily in the form of limited exemptions and adjustments (Table 6). Administratively, the decision-makers were not prepared for such an eventuality and thus 
were forced frequently to adjust their approach on an ad-hoc basis. A week after the full closure, once the urgent demand for limited cross-border traffic became evident, a generic, not mapped-out border zone was established to allow cross-border communities to function, with cross-border traffic permitted on a demonstrable needs basis [143]. Given the rising number of cases in Melbourne and seeding of SARS-CoV2 into regional Victoria, NSW reacted and stipulated a very narrow border corridor on 20 July 2020 (Figure 5) [144], which, not surpassingly, resulted in severe restrictions on cross-border movements in Albury-Wodonga. These rapidly changing conditions brought about confusion among the border communities, coupled with a growing sense of frustration and resentment at the seemingly arbitrary boundaries [145].

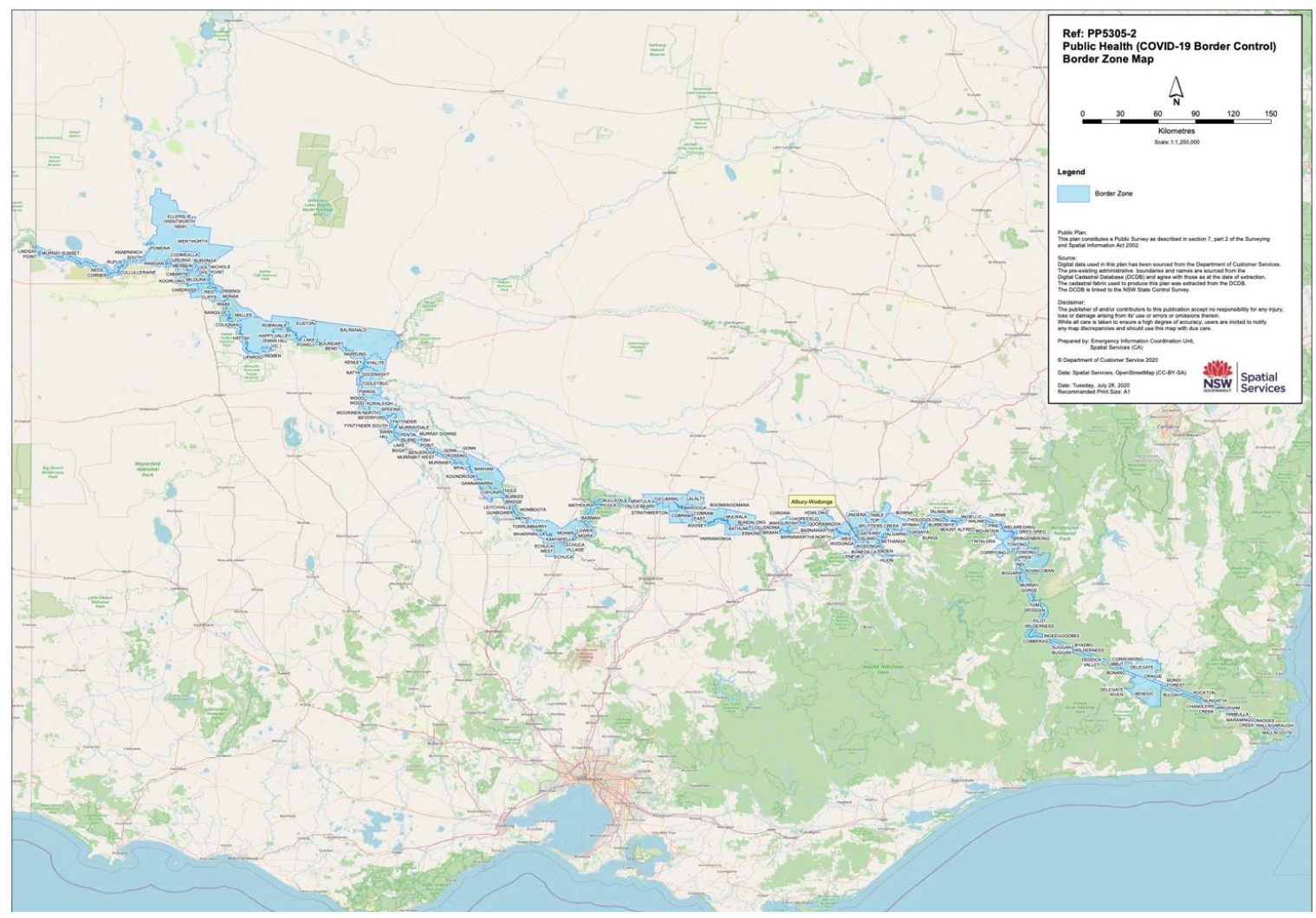

Figure 5. Map of the NSW-defined COVID-19 border buffer zone between New South Wales and Victoria, 28 July 2020 [146].

Table 6. Border Control orders NSW (8 July-23 November 2020).

\begin{tabular}{|c|c|c|}
\hline Title & Duration & Ref. \\
\hline Public Health (COVID-19 Border Control) Order 2020 & 8-22 July & [143] \\
\hline Public Health (COVID-19 Border Control) Amendment Order & 22-22 July & [147] \\
\hline Public Health (COVID-19 Border Control) Amendment (Border Community) Order & 22-24 July & [148] \\
\hline Public Health (COVID-19 Border Control) Amendment (Vulnerable Persons) Order & 24-25 July & [149] \\
\hline Public Health (COVID-19 Border Control) Amendment (Medical \& Hospital Services) Order & 25 July-7 August & [150] \\
\hline Public Health (COVID-19 Border Control) Amendment Order (No 2) & 7-13 August & [151] \\
\hline Public Health (COVID-19 Border Control) Amendment (Transiting ACT Residents) Order & 13-17 August & [152] \\
\hline Public Health (COVID-19 Border Control) Order 2020 Remote Communities Amendment & 13 August- & [153] \\
\hline Public Health (COVID-19 Border Control) Order 2020 School Exemption Amendment & 20 August- & [154] \\
\hline Public Health (COVID-19 Border Control) Amendment Order (No 3) & 18 August-1 September & [155] \\
\hline Public Health (COVID-19 Border Control) Order 2020 (Flight Crew Exemption Amendmt 4 & 4 September- & [156] \\
\hline Public Health (COVID-19 Border Control) Amendment Order (No 4) & 4-12 September & [157] \\
\hline Public Health (COVID-19 Border Control) Amendment Order (No 5) & 12-17 September & [158] \\
\hline Public Health (COVID-19 Border Control) Amendment Order (No 6) & 17-25 September & [159] \\
\hline Public Health (COVID-19 Border Control) Amendment Order (No 7) & 25-28 September & [160] \\
\hline Public Health (COVID-19 Border Control) Amendment Order (No 8) & 28 September-2 October & [161] \\
\hline Public Health (COVID-19 Border Control) Order (No 2) 2020 & $2-16$ October & [162] \\
\hline Public Health (COVID-19 Border Control) (No 2) Amendment Order & 16 October-23 November & [163] \\
\hline Public Health (COVID-19 Border Control) Order (No 2) Repeal Order 2020 & 23 November & [164] \\
\hline
\end{tabular}


The boundaries were adjusted on 28 July to add communities adjacent to central Wodonga, which had a high number of residents working in Albury (Figure 6) [146]. While the new boundaries benefitted the majority of Albury-Wodonga residents, they did little to alleviate the plight of some farmers who owned land on either side of the river, some of which was just outside the bubble. It also affected agricultural workers, such as grain and hay harvesting contractors owning high-capital, specialized machinery and who worked on a regional or catchment basis with little if any regard to state boundaries.

Following the failure of ringfencing Melbourne and environs, as well as a display of selfishness by some residents blatantly flaunting the movement restrictions [165], Victoria moved on 2 August to declare a state-wide stage 3 locked down [166] and stage 4 (with curfew) for Melbourne [167]. While the border zone boundaries did not change at that stage, New South Wales restricted the nature of cross-border access [151]. Once the Victorian cases decreased again, NSW agreed (effective 4 September 2020) to a new and much wider cross-border zone which took into account the need for movement of agricultural workers and contractors (Figure 7) [168]. The border zone boundaries were adjusted on 15 October 2020, expanding the zone to the Alpine areas (Figure 8). The enforcement of the crossborder movement restrictions relied on permits that needed to be verified individually at roadblocks (Figure 9), with reports of persons trying to be smuggled through the control points $[169,170]$. Once the Melbourne outbreak had been suppressed, the border controls were lifted on 23 November 2020 [164].

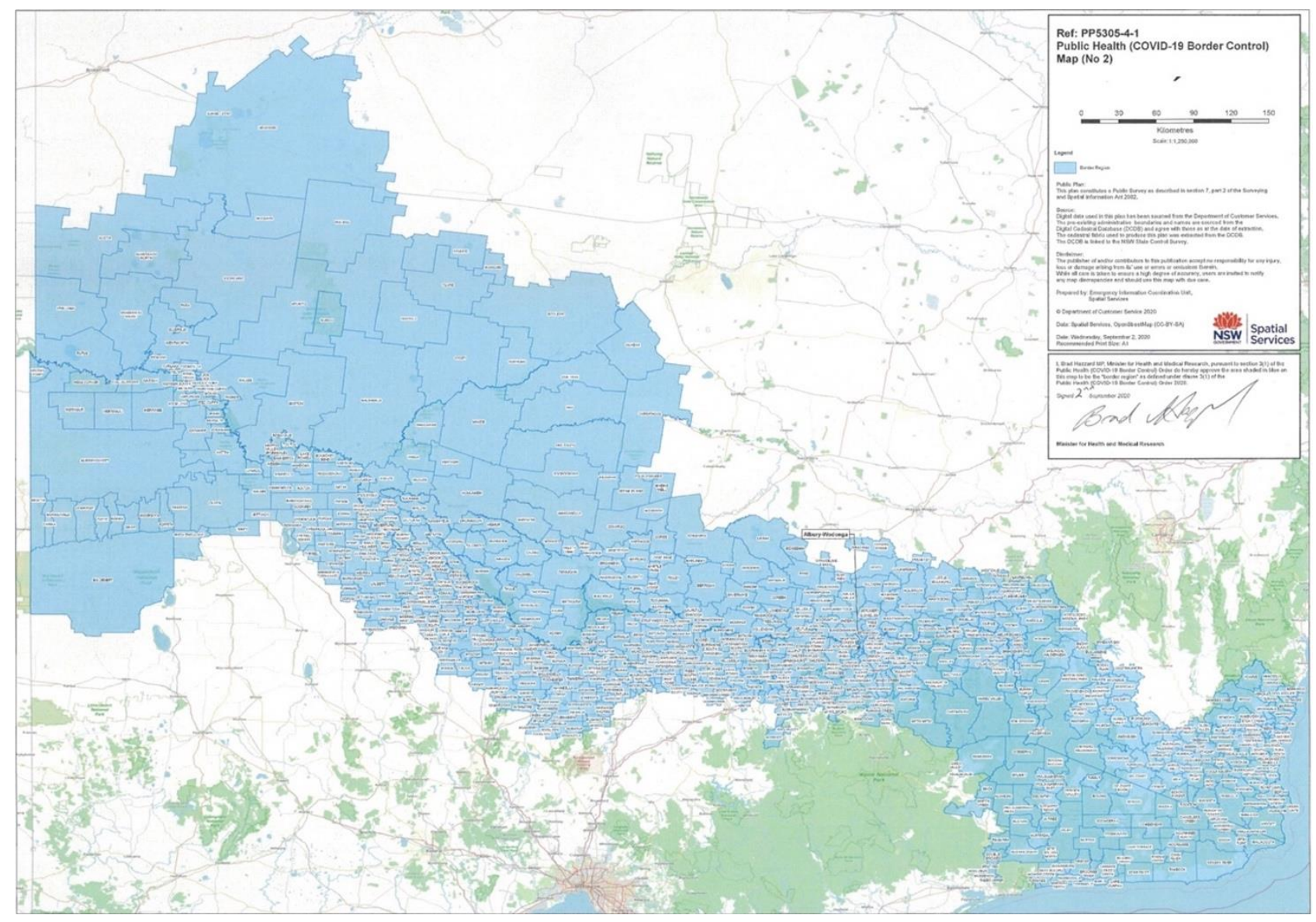

Figure 6. Map of the NSW-defined COVID-19 border buffer zone between New South Wales and Victoria, 2 September 2020 [168]. 


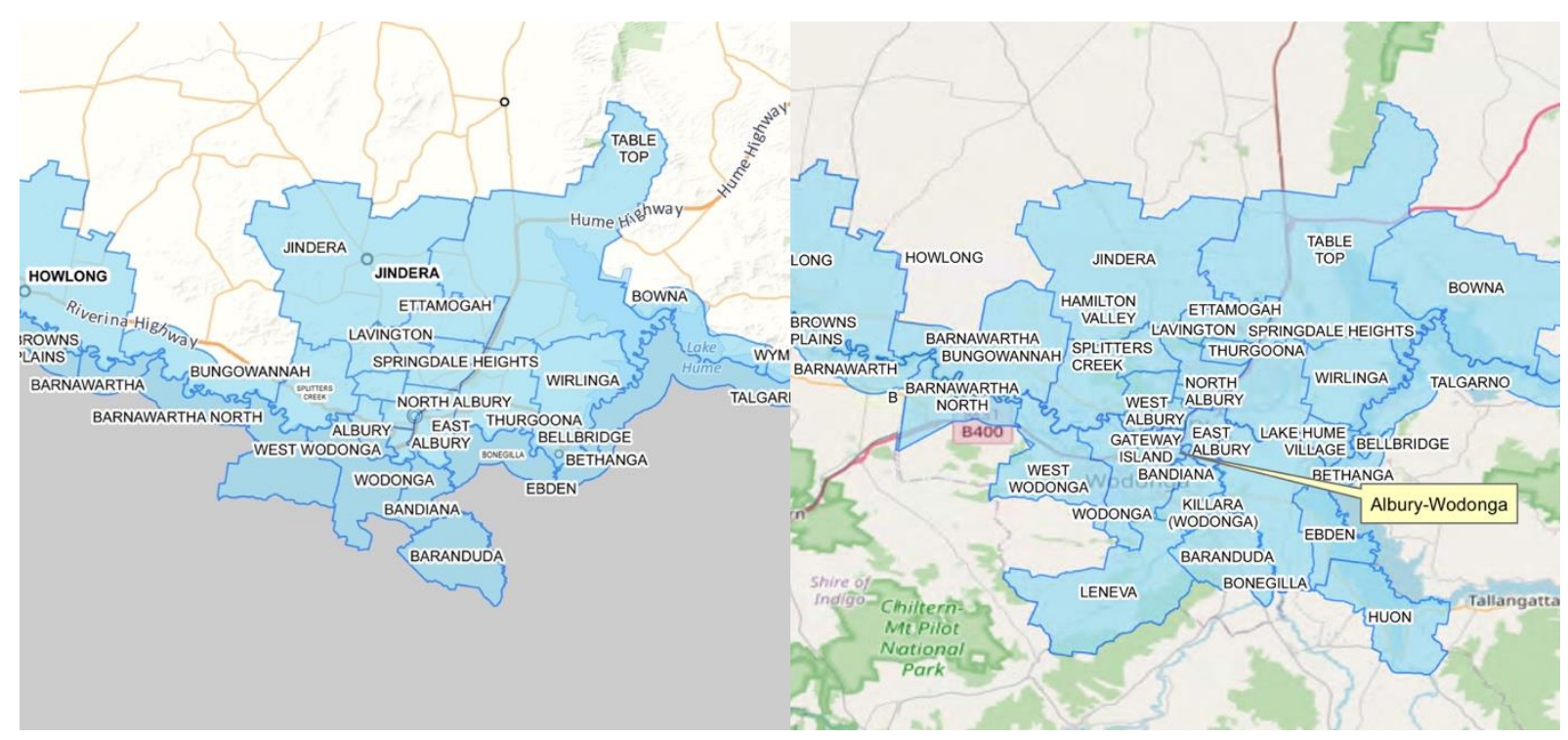

(a) 20 July 2020

(b) 28 July 2020

Figure 7. Boundary adjustments of the NSW-defined COVID-19 border buffer zone between New South Wales and Victoria in the immediate Albury-Wodonga area, July 2020 [144,146].

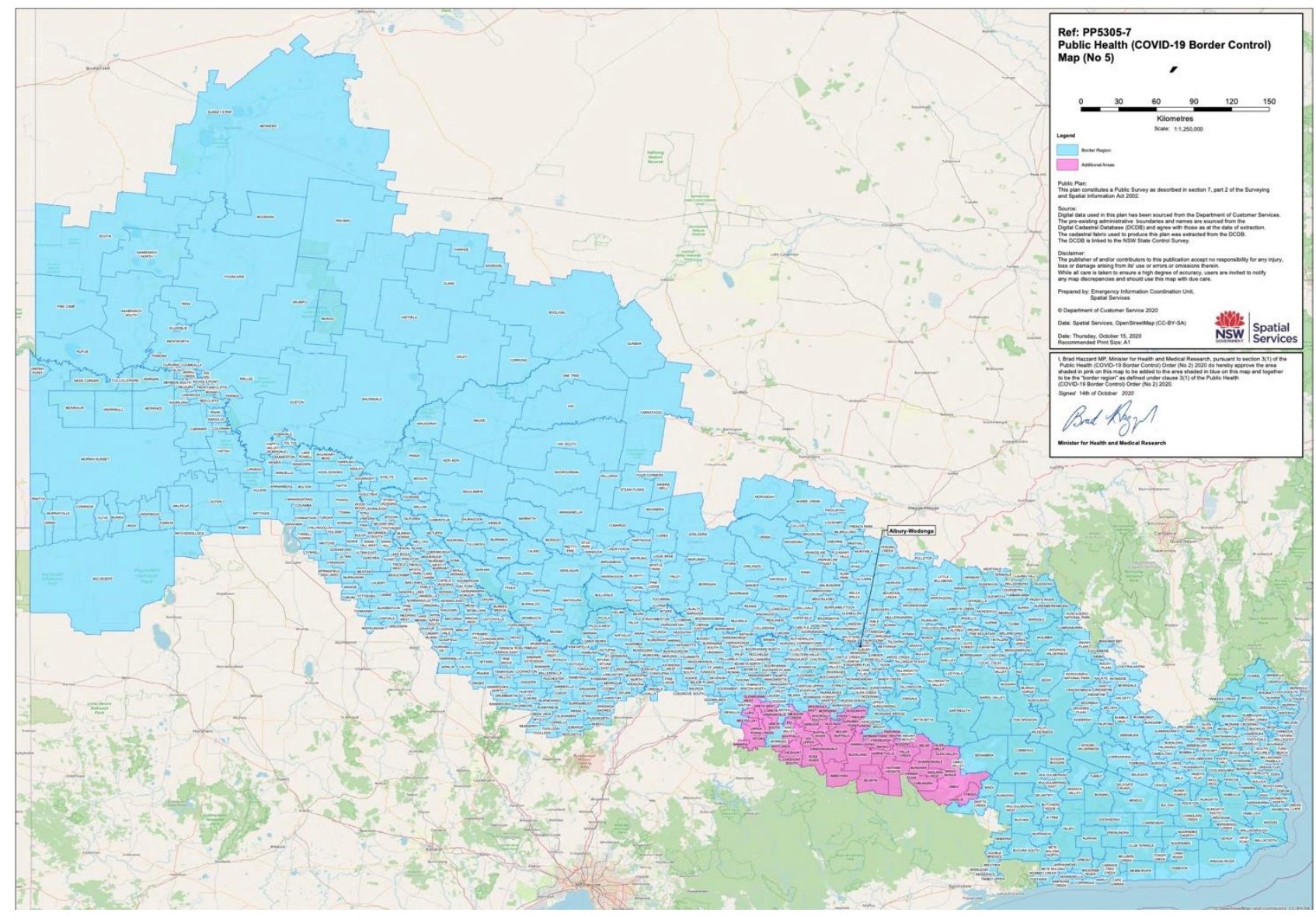

Figure 8. Map of the NSW-defined COVID-19 border buffer zone between New South Wales and Victoria, 15 October 2020 [171]. 


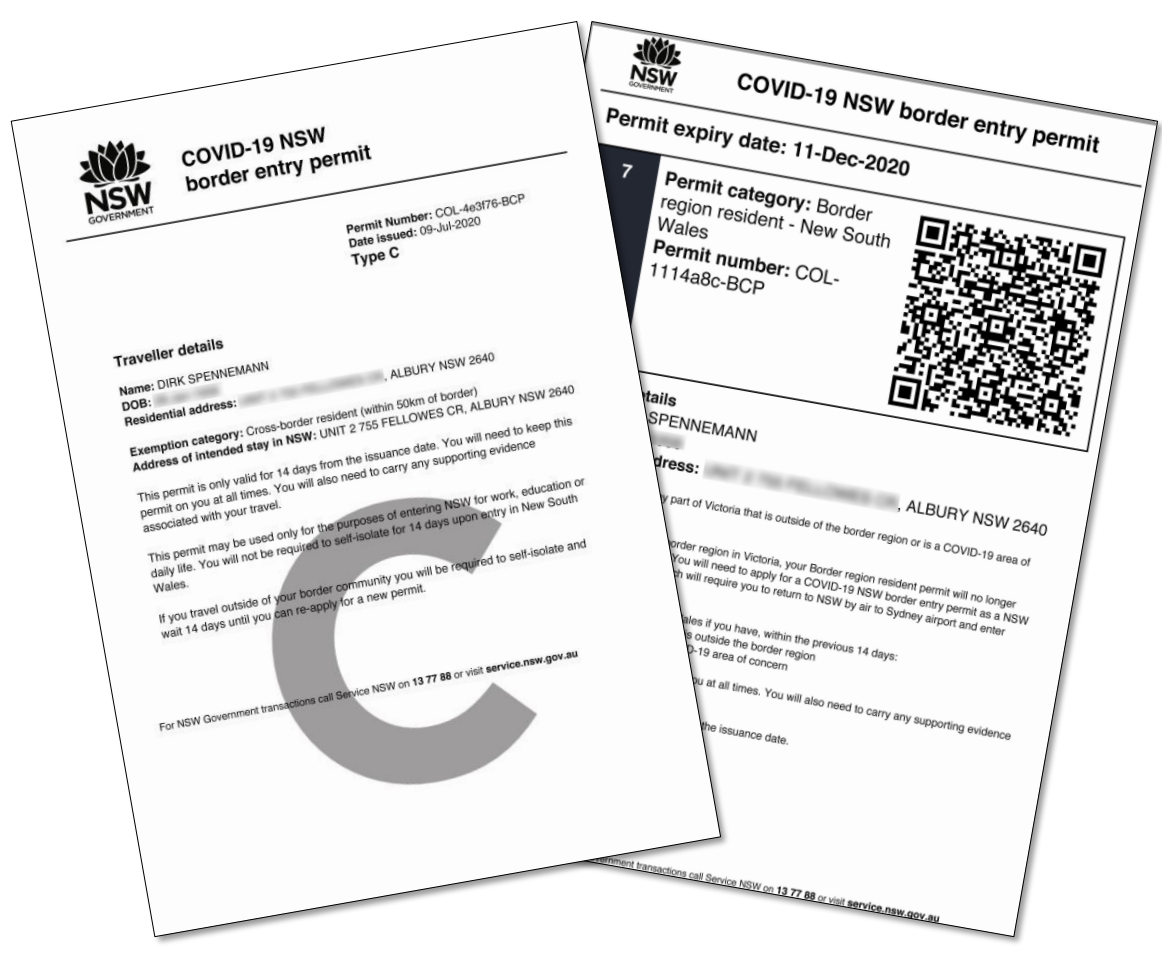

Figure 9. Ephemera-Border permits to enter New South Wales from Victoria (Australia). (Left): early type in July 2020, (Right): late type (example December 2020) [172].

When Sydney detected an outbreak in its Northern Beaches area on 16 December 2020 and the cluster grew in subsequent days, the Victorian government began to exclude visitors from designated "red" zones [173] and subsequently closed the border with NSW altogether on 1 January 2021 [174]. In this case, however, the Victorian government established a "bubble" for the border communities that was more generously zoned and was based on LGA boundaries (Figure 10). While the Victorian government issued a flurry of modifications to the border crossing regulations (Table 7), these did not affect the shape of the bubble. A range of temporary structures was erected accompanied by traffic controls and signage (Figures 11 and 12) [175]. The stringent roadblocks were removed on 29 January 2021 and replaced by mobile random checks [176] to detect individuals coming from restricted areas.

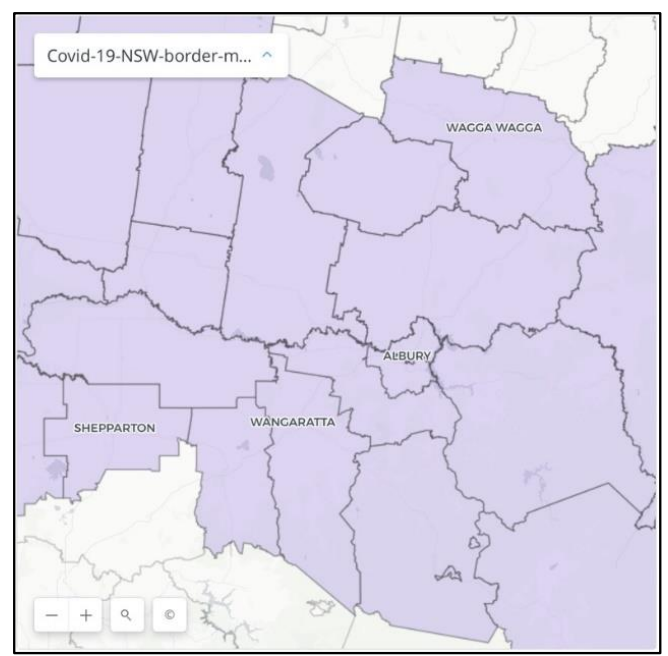

Figure 10. Map (section) of the Victoria-defined COVID-19 border buffer zone between New South Wales and Victoria, 3 February 2021 [177]. 
Table 7. Border Control orders Victoria (18 December 2020-2021).

\begin{tabular}{|c|c|c|}
\hline Title & Duration & Reference \\
\hline New South Wales Border Crossing Permit Scheme Directions & 18-20 December & [173] \\
\hline New South Wales Border Crossing Permit Scheme Directions (No. 2) & 20-30 December & [178] \\
\hline New South Wales Border Crossing Permit Scheme Directions (No. 3) & 30 December-1 January & [174] \\
\hline New South Wales Border Crossing Permit Scheme Directions (No. 4) & 1-1 January & [179] \\
\hline New South Wales Border Crossing Permit Scheme Directions (No. 5) & 1-3 January & [180] \\
\hline New South Wales Border Crossing Permit Scheme Directions (No. 6) & 3-5 January & {$[181]$} \\
\hline New South Wales Border Crossing Permit Scheme Directions (No. 7) & 5-7 January & [182] \\
\hline New South Wales Border Crossing Permit Scheme Directions (No. 8) & 7-8 January & [183] \\
\hline New South Wales and Queensland Border Crossing Scheme Directions & 8-11 January & [184] \\
\hline Victorian Border Crossing Permit Directions & 11-12 January & [185] \\
\hline Victorian Border Crossing Permit Directions (No. 2) & 12-17 January & [186] \\
\hline Victorian Border Crossing Permit Directions (No. 3) & 17-22 January & [187] \\
\hline Victorian Border Crossing Permit Directions (No. 4) & 22-29 January & [188] \\
\hline Victorian Border Crossing Permit Directions (No. 5) & 29 January- & [176] \\
\hline
\end{tabular}

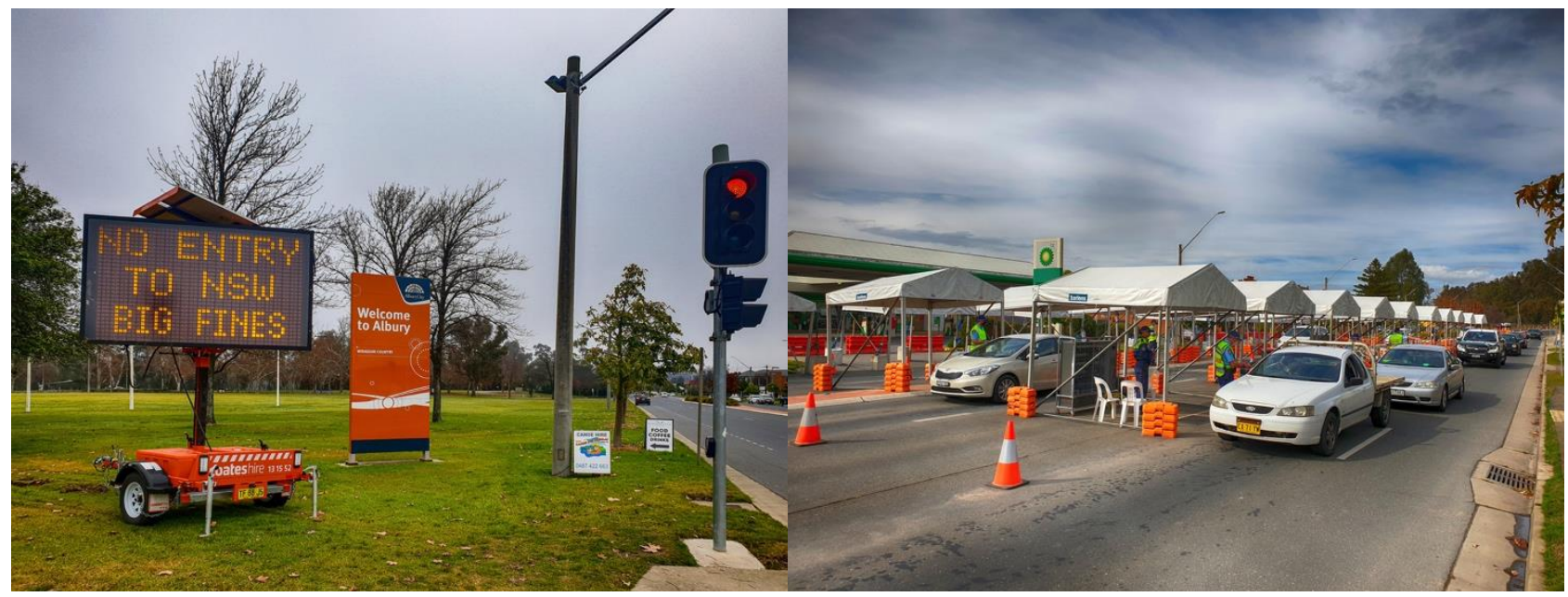

Figure 11. Border controls when entering New South Wales from Victoria (Australia) (Left): total border closure, 7 July 2020, (Right): travel permit checks 9 September 2020 (Wodonga Place, Albury, NSW) (Photos by the author).
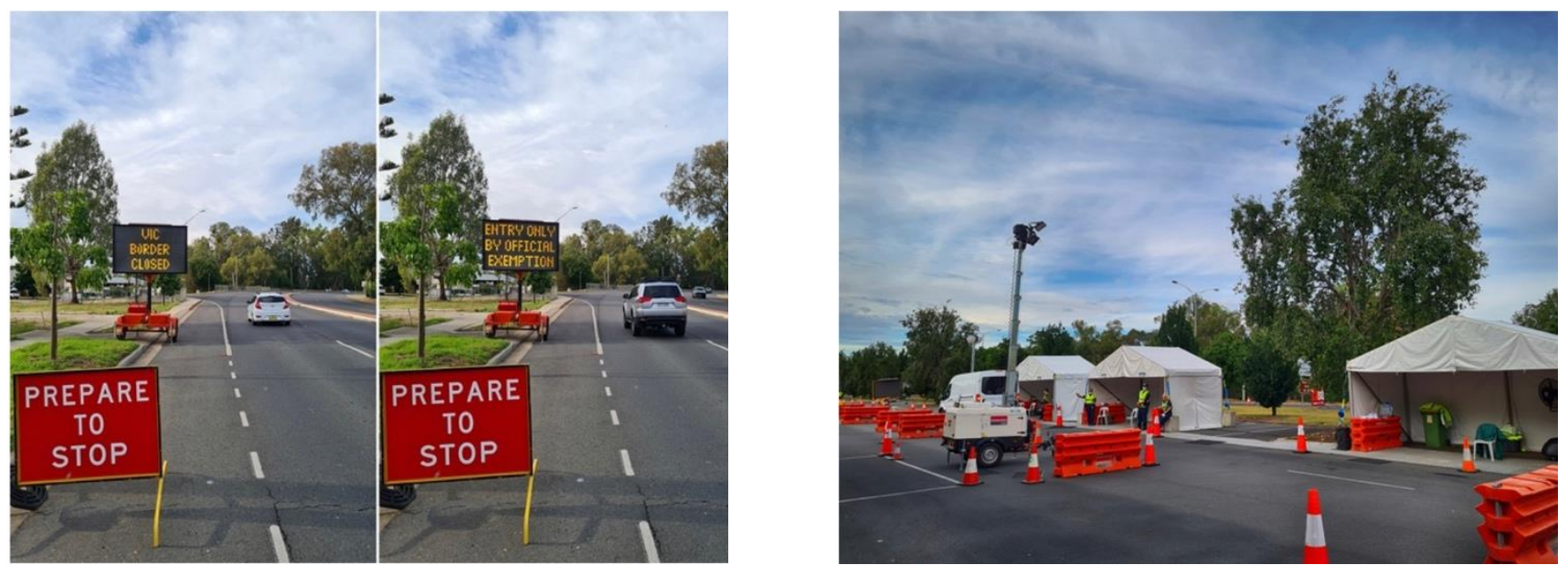

Figure 12. Border controls when entering Victoria from New South Wales. (Left): border closure warning sign. (Right): border control point, both 4 January 2021 (Left): Wodonga Place, Albury; (Right): Gateway Island, Wodonga.

Following the escape of a more infectious strain of COVID-19 from Melbourne hotels housing overseas returnees in early February 2021, the Victorian government imposed a 
five-day stage 4 lockdown on 12 February 2021 [189,190]. Whereas previous restrictions in the border region either applied on both sides (March-May 2020) or prevented out-ofzone travel, the stage 4 lockdown meant that Victorian citizens (unless essential workers) could only leave their home for a narrow set of reasons and then only within a $5 \mathrm{~km}$ radius [189]. Unlike the previous border closures, this lockdown had direct implications on Victorian residents unable to travel to their places of work in Albury, with Albury employers impacted to varying degrees, such as those at Albury High School [191,192]. Additionally, Albury residents working and students studying in Wodonga faced the situation that their places of work and study were closed.

\section{Conclusions and Implications}

The COVID-19 pandemic and the associated public health measures including border closures and associated controls, effectively cut or impacted cross-border travels between Albury and Wodonga from 31 March to mid-May 2020, from 8 July until 22 November 2020 (initiated by NSW), between 1 and 29 January 2021 (initiated by Victoria) and between 12 and 17 February 2021 (also initiated by Victoria). These were the first full closures since the influenza epidemic 100 years earlier.

Yet unlike 1918/19, when the border closures affected only a small number of people living on and working on the other side of the border, the 2020/21 pandemic has impacted integrated cross-border communities causing significant social disruption and considerable economic cost. Self-employed rural contractors, paying off loans on capital-intensive specialised machinery, were cut off from their clients, while at the same time primary producers were left without the harvesters they had hired and had relied on.

While economic relief measures, such as job keeper, allow offsetting some of the economic costs, the disruption of the social fabric is considerable. With the close integration of the public health system, for example, border closures and state-based lockdown directives have a measurable impact on the ability of relatives to attend obstetrics events and relatives to visit patients in the oncology facilities. Clearly, the spatial confinement of the spread of a disease through ring-fencing or state-wide travel restrictions is a valid, logical and inherently adaptable concept in the toolkit of public health responses to a pandemic $[20,21]$. The use of border closures to prevent interstate travel, especially when wielded by metropolitan-focussed decision-makers, is a blunt tool that causes disproportionate disruptions in cross-border communities on a trajectory of social and economic integration.

By and large, metropolitan-centred decision-making in both Victoria and New South Wales has a history of treating the respective border regions as a geographically and politically peripheral space which consequently saw little investment and development, unless it directly benefitted metropolitan interests. Closing the state border, coupled with the arbitrary delineation of the border zone by New South Wales during the early period of the border closure in July 2020 is a case in point [144]. While the border zone was well intentioned, it was bereft of an understanding of the realities on the ground. Another example is the arbitrary definition of a $5 \mathrm{~km}$ movement radius by the Victorian government [189], which makes some sense in densely populated metropolitan Melbourne, but less so in rural Victoria where population densities are lower and travel distances to essential services are longer [193].

While Australia has, at the time of writing, avoided a large-scale COVID-19 pandemic within its borders, multiple seeding events have occurred that could be contained. Some of these required the closures of borders, others did not. While the current temporary border closure regimes can be reinstated at short notice, there is a need to develop more nuanced containment regimes, if not for a re-emergence of the COVID-19 pandemic, then for future events.

As the vaccines are being administered to contain COVID-19, attention is moving to consider the future make-up of studying [194], working [195], living [196] and commuting [197]. There is the risk that hard border closures are interpreted as a success without 
reflection. Given the nature of communicable diseases, coupled with the high mobility of the 21st-century society, border closures based on physio-graphic features such as rivers are a blunt policy tool that, while easily administrable, causes significant social and economic harm. Moreover, they are no more secure and foolproof than other methods of ring-fencing. Human nature is such that there will be individuals who will place their personal economic and social interests over the well-being of the wider community. History has shown that hard borders are only as effective as the ability, and the political will, to enforce these. Hard interstate borders between News South Wales and Victoria proved ineffective during the 1919 influenza pandemic because there was a sufficient number of people determined to bypass checkpoints. There were sufficient indications during the COVID-19 pandemic that individuals were prepared to do the same, including hiding in the trunk of a car.

For any containment measure to be successful, it requires a "buy-in" by the general community. While solutions for an adaptive system of containment can avoid generic and broad-brush epidemiological control measures [22], it is a question of political will whether such ideas will come to fruition. Given that other zoonotic coronaviruses akin to SARS-CoV-2 are currently in existence in various host species [198], it is inevitable that some of these coronaviruses will emerge as yet another major threat to humans [199].

One of the lessons of the 2020/21 pandemic will be to either re-evaluate the wisdom of a close social and economic integration of border communities, which would be a backwards step, or to future-proof these communities by developing strategies, effectively public health management plans, to avoid a repeat if and when the next pandemic strikes.

Funding: This research received no external funding.

Data Availability Statement: Not applicable.

Acknowledgments: I am indebted to the Wodonga Historical Society for permission to use the image reproduced as Figure 2.

Conflicts of Interest: The author declares no conflict of interest.

\section{References}

1. WHO. Naming the Coronavirus Disease (COVID-19) and the Virus That Causes It. Available online: https:/ /www.who.int/ emergencies / diseases / novel-coronavirus-2019/technical-guidance/naming-the-coronavirus-disease-(covid-2019)-and-thevirus-that-causes-it (accessed on 10 August 2020).

2. Gilbert, M.; Pullano, G.; Pinotti, F.; Valdano, E.; Poletto, C.; Boëlle, P.-Y.; d'Ortenzio, E.; Yazdanpanah, Y.; Eholie, S.P.; Altmann, M. Preparedness and vulnerability of African countries against importations of COVID-19: A modelling study. Lancet 2020, 395, 871-877. [CrossRef]

3. Moloney, K.; Moloney, S. Australian Quarantine Policy: From centralization to coordination with mid-Pandemic COVID-19 shifts. Public Adm. Rev. 2020, 80, 671-682. [CrossRef] [PubMed]

4. Lee, K.; Worsnop, C.Z.; Grépin, K.A.; Kamradt-Scott, A. Global coordination on cross-border travel and trade measures crucial to COVID-19 response. Lancet 2020, 395, 1593. [CrossRef]

5. Storen, R.; Corrigan, N. COVID-19: A Chronology of State and Territory Government Announcements (Up Until 30 June 2020); Parliamentary Library Research Paper Series Parliamentary Library; Commonwealth of Australia: Canberra, Australia, 2020.

6. Lyu, W.; Wehby, G.L. Comparison of estimated rates of coronavirus disease 2019 (COVID-19) in border counties in Iowa without a stay-at-home order and border counties in Illinois with a stay-at-home order. JAMA Netw. Open 2020, 3, e2011102. [CrossRef]

7. Solis, J.; Franco-Paredes, C.; Henao-Martínez, A.F.; Krsak, M.; Zimmer, S.M. Structural vulnerability in the US revealed in three waves of COVID-19. Am. J. Trop. Med. Hyg. 2020, 103, 25-27. [CrossRef]

8. Graichen, H. What is the difference between the first and the second/third wave of Covid-19?-German perspective. J. Orthop. 2021. [CrossRef]

9. Gutiérrez, P.; Clarke, S.; Kirk, A. Covid World Map: Which Countries Have the Most Coronavirus Cases and Deaths? The Guardian, 2 June 2021; p. 3.

10. Diez, T.; Stetter, S.; Albert, M. The European Union and border conflicts: The transformative power of integration. Int. Organ. 2006, 60, 563-593. [CrossRef]

11. Felbermayr, G.; Gröschl, J.; Steinwachs, T. The trade effects of border controls: Evidence from the European Schengen Agreement. JCMS: J. Common Market. Stud. 2018, 56, 335-351. [CrossRef]

12. Warf, B. A Review of "Geographies of Globalization". Prof. Geogr. 2010, 62, 289-290. [CrossRef]

13. Norman, K.P. Reluctant Reception: Refugees, Migration and Governance in the Middle East and North Africa; Cambridge University Press: Cambridge, UK, 2020. 
14. Wassenberg, B. The Schengen Crisis and the End of the "Myth" of Europe Without Borders. Bord. Glob. Rev. 2020, 1, 30-39. [CrossRef]

15. Alexander-Nathani, I. Criminalizing the Mediterranean Crossing: The Regulation of Migrants, Refugees, and Rescue Missions at Europe's Southern Borders. In African Migrants and the Refugee Crisis; Springer: Berlin/Heidelberg, Germany, 2021; pp. 261-276.

16. Radil, S.M.; Castan Pinos, J.; Ptak, T. Borders resurgent: Towards a post-Covid-19 global border regime? Space Polity 2020, 9, 132-140. [CrossRef]

17. Chinazzi, M.; Davis, J.T.; Ajelli, M.; Gioannini, C.; Litvinova, M.; Merler, S.; y Piontti, A.P.; Mu, K.; Rossi, L.; Sun, K. The effect of travel restrictions on the spread of the 2019 novel coronavirus (COVID-19) outbreak. Science 2020, 368, 395-400. [CrossRef]

18. Chaudhry, R.; Dranitsaris, G.; Mubashir, T.; Bartoszko, J.; Riazi, S. A country level analysis measuring the impact of government actions, country preparedness and socioeconomic factors on COVID-19 mortality and related health outcomes. EClinicalMedicine 2020, 25, 100464. [CrossRef]

19. Cousins, S. New Zealand eliminates COVID-19. Lancet 2020, 395, 1474. [CrossRef]

20. Goh, K.-T.; Cutter, J.; Heng, B.-H.; Ma, S.; Koh, B.K.; Kwok, C.; Toh, C.-M.; Chew, S.-K. Epidemiology and control of SARS in Singapore. Ann. Acad. Med. Singap. 2006, 35, 301. [PubMed]

21. Haydon, D.T.; Cleaveland, S.; Taylor, L.H.; Laurenson, M.K. Identifying reservoirs of infection: A conceptual and practical challenge. Emerg. Infect. Dis. 2002, 8, 1468-1473. [PubMed]

22. Spennemann, D.H.R. A number's game: Towards a solution to the policing of ringfenced COVID hotspots. Health Promot. J. Aust. 2011, 32. [CrossRef]

23. Parker, M.; Spennemann, D.H.R. Anthropause on audio: The effects of COVID-19 pandemic on church bell ringing in New South Wales (Australia). J. Acoust. Soc. Am. 2020, 148, 3102-3106. [CrossRef] [PubMed]

24. Clarsen, G.W. Automobiles and Australian modernisation: The Redex Around-Australia trials of the 1950s. Aust. Hist. Stud. 2010, 41, 352-368. [CrossRef]

25. Bureau of Meteorology. Map of Climate Zones of Australia. Available online: http://www.bom.gov.au/climate/how/ newproducts/images/zones.shtml (accessed on 10 February 2021).

26. Abley, S.; Cassar, O.; Khinsoe, E.; Marks, L.; Vanderzwan, O.; Palermo, C.; Kleve, S. Do Farmers' Markets Offer Consumers an Available and Affordable Supply of Fresh Fruit and Vegetables Compared to Other Retail Outlets in Australia? J. Hunger Environ. Nutr. 2020, 15, 827-834. [CrossRef]

27. Munawar, H.S.; Khan, S.I.; Qadir, Z.; Kouzani, A.Z.; Mahmud, M. Insight into the Impact of COVID-19 on Australian Transportation Sector: An Economic and Community-Based Perspective. Sustainability 2021, 13, 1276. [CrossRef]

28. National Library of Australia. Trove. Australian and Online Resources; National Library of Australia: Canberra, Australia, 2021.

29. Mollison, A.F. An Overlanding Diary: April-December 1837, from Uriara Station, on the Murrumbidgee, to Port. Phillip, Victoria; Randell, J., Ed.; Mast Gully Press: Melbourne, Australia, 1837.

30. Lane, H. Report of the Select Committee on the Aborigines, Victoria. In Votes and Proceedings of the Legislative Assembly: With Copies of the Various Documents Ordered by the Assembly to be Printed; John Ferres, Government Printer: Melbourne, Australia, 1859; Volume 25, pp. 1858-1859.

31. Wesson, S. An Historical Atlas of Aborigines of Eastern Victoria and South-Eastern NSW; School of Geography and Environmental Science: Melbourne, Australia, 2000.

32. Andrews, A.E.J. Hume and Hovell, 1824; Blubber Head Press: Hobart, Australia, 1981.

33. Spennemann, D.H.R. Nineteenth Century Indigenous Land Use of Albury (NSW), as Reflected in the Historic Sources; Institute for Land, Water and Society, Charles Sturt University: Albury, Australia, 2015; Volume 83.

34. Anonymous. A Visit to Albury. Available online: https://trove.nla.gov.au/newspaper/article/70604201 (accessed on 7 June 2021).

35. La Trobe, C.J. Claims to leases of Crown Land beyond the Settled Districts. Murray District. Argus, 25 July 1848 ; pp. 1-4.

36. Spennemann, D.H.R. Turk's Head at the Union Bridge. From Licenced Hotel to Regional Museum; Institute for Land, Water and Society Report 978-1-86-467309-8; Institute for Land, Water and Society, Charles Sturt University: Albury, Australia, 2018.

37. Browne, R. Advertisement. Australian, 2 March 1838; p. 3.

38. Reid, D. Old Memories. Albury Banner, 10 October 1902; p. 36.

39. Andrews, A. The History of Albury 1824 to 1895; Adams, Cooper and Adams: Albury, Australia, 1912.

40. Fraser, D.J. Nomination for an Historic Engineering Marker of the John Foord Bridge of the River Murray at CorowaI; The Engineering Heritage Committee: Sydney, Australia, 2001.

41. Spennemann, D.H.R. $N^{\circ} 532$ Kiewa Street, Albury, NSW. An Historical Analysis of the Site and an Assessment of Heritage Values; Johnstone Centre Report The Johnstone Centre, Charles Sturt University: Albury, Australia, 2003.

42. Lonsdale, W. Belvoir. In Victoria Government Gazette; Victorian Government: Melbourne, Australia, $1852 ;$ p. 474.

43. Bowen, G.F. Town and Parish of Wodonga. In Victoria Government Gazette; Victorian Government: Melbourne, Australia, 1874; p. 1469.

44. Dunlop, A.J. Wodonga. Over River and Plain; The Hawthorn Press: Melbourne, Australia, 1976.

45. Clark, I. Scars in the Landscape: A Register of Massacre Sites in Western Victoria, 1803-1859; Aboriginal Studies Press: Canberra, Australia, 1995. 
46. Shaw, A.G.L. A History of the Port. Phillip District: Victoria before Separation; Melbourne University Publishing: Melbourne, Australia, 2003.

47. An Act for the Better Government of Her Majesty's Australian Colonies United Kingdom; Ministry for Health and Medical Research: Sydney, Australia, 1850; Volume 13.

48. Stuart, I. The surveyors' lot: Making landscapes in New South Wales. Australas. Hist. Archaeol. 2007, 25, 43-55.

49. Park, M.M. A Review of the Victoria-New South Wales Border. J. Spat. Sci. 2005, 50, 119-120. [CrossRef]

50. Patterson, G. The New South Wales-Victorian border: A note on its determination. Aust. Hist. Stud. 1962, 10, 214-221. [CrossRef]

51. Clark, S.D. The River Murray Question: Part I-Colonial Days. Melb. Univ. Law Rev. 1971, 8, 11-40.

52. An Act for Granting Duties of Customs; Ministry for Health and Medical Research: Sydney, Australia, 1852.

53. An Act for the Granting Duties of Customs New South Wales; Ministry for Health and Medical Research: Sydney, Australia, 1855; Volume 19.

54. An Act to Legalize Certain Arrangements Made Between the Governments of New South Wales and South Australia Relative to the Customs Duties on Goods Imported into New South Wales Through South Australia by Way of the River Murray; Ministry for Health and Medical Research: Sydney, Australia, 1855; Volume 19.

55. Anonymous, Albury. The customs duties on the Murray. Empire, 14 June 1855; p. 8.

56. Anonymous. New South Wales. South. Australian Register, 4 December 1855; p. 3.

57. An Act to Authorize Certain Arrangements Respecting Customs Duties on Goods Brought into New South Wales by and across the River Murray; Ministry for Health and Medical Research: Sydney, Australia, 1861; Volume 25.

58. Patterson, G.D. The Murray River Dispute, 1853-1880. Bus. Arch. Hist. 1962, 2, 122-136. [CrossRef]

59. Patterson, G.D. The Tariff in the Australian Colonies 1856-1900; F.W. Cheshire: Melbourne, Australia, 1968.

60. Andrews, A. History of Albury. Chapter XV-1872-1874. Albury Banner, 2 February 1912; p. 37.

61. Pennay, B. From Colonial to State Border: A Federation History of the Social Construction of the Border between New South Wales and Victoria as a Frontier, Barrier ad Contact Zone; Charles Sturt University: Albury, Australia, 2001.

62. Anonymous. Utilisation of the Murray. Sydney Morning Herald, 9 January 1862; p. 4.

63. Lougheed, A.L. Economic Effects of Railway Construction in Australia, 1861-1914; Working Papers in Economics Department of Economics, University of Queensland: Brisbane, Australia, 1977.

64. Robinson, M.E. The New South Wales Wheat Frontier 1851 to 1911; Research School of Pacific Studies, Department of Human Geography, The Australian National University: Canberra, Australia, 1976; Volume HG/10.

65. Waugh, A. Victorian Railway Maps 1860-2000. Available online: http://www.vrhistory.com/VRMaps/ (accessed on 31 December 2020).

66. Holmes, L. Albury's Railway Centenary 1881-1981; Albury and District Historical Society: Albury, Australia, 1981.

67. Smith, R.H. Transport Competition in Australian Border Areas: The Example of Southern New South Wales. Econ. Geogr. 1963, 39, 1-13. [CrossRef]

68. An Act to Constitute the Commonwealth of Australia United Kingdom. 1900. Available online: https://www.aph.gov.au/ About_Parliament/Senate/Powers_practice_n_procedures/Constitution/preamble (accessed on 31 December 2020).

69. Rose, A.J. The border between Queensland and New South Wales: A study of political geography in a Federal Union. Aust. Geogr. 1955, 6, 3-18. [CrossRef]

70. Logan, W. The changing landscape significance of the Victoria-South Australia boundary. Ann. Assoc. Am. Geogr. 1968, 58, 128-154. [CrossRef]

71. Pearce, G.F. Provisional Regulations under the Defence Act 1903-1910. Amendment to Commonwealth Military Regulation 5. (Statutory Rule 1911 no 199). C.17113; J. Kemp: Melbourne, Australia, 1911.

72. Long, G. To Benghazi. Australia in the War of 1939-1945. Series 1-Army; Australian War Memorial: Canberra, Australia, 1952; Volume 1.

73. Fujak, H.; Frawley, S.M. The Barassi Line: Quantifying Australia's Great. Sport. Tradit. 2013, 30, 93-110.

74. Young, J. Proclamation [regarding catle from Victoria]. In New South Wales Government Gazette; Ministry for Health and Medical Research: Sydney, Australia, 1861; p. 1672.

75. Young, J. Proclamation [regarding catle from Victoria]. In New South Wales Government Gazette; Ministry for Health and Medical Research: Sydney, Australia, 1861; p. 2318.

76. O'Shanassy, J. Rules under the Pleuro-Pneumonia Act. In Victoria Government Gazette; Victorian Government: Melbourne, Australia, 1861; p. 2365.

77. Griffith, C.J.; Rudall, J.T.; Ralph, T.S.; Black, T.; Mccoy, F. Pleuro-Pneumonia. Progress Report of the Royal Commission to Enquire into the Origin and Nature of the Disease Known as Pleuro-Pneumonia; John Ferres: Melbourne, Australia, 1863; p. 5.

78. Newton, L.G. Contagious bovine pleuropneumonia in Australia: Some historic highlights from entry to eradication. Aust. Vet. J. 1992, 69, 306-317. [CrossRef] [PubMed]

79. Smith, W.S. The History of Sheep Scab in South Australia; W.S. Smith: Adelaide, Australia, 1975.

80. Arevect for the prevention of Scab in Sheep [NSW]. An Act for the pntion of Scab in Sheep. V.R. XXIV N ${ }^{\circ}$ 9. In Government Gazette of the State of New South Wales; Ministry for Health and Medical Research: Sydney, Australia, 1861; pp. 755-761.

81. Anonymous. The Anthax Regulations. Albury Banner, 15 January 1904; p. 15. 
82. Spreeuwenberg, P.; Kroneman, M.; Paget, J. Reassessing the global mortality burden of the 1918 influenza pandemic. Am. J. Epidemiol. 2018, 187, 2561-2567. [CrossRef]

83. Fitzgerald, J.D. Proclamation [regarding pneunomic influenza]. In Government Gazette of New South Wales; Ministry for Health and Medical Research: Sydney, Australia, 1919; pp. 593-594.

84. Fitzgerald, J.D. Proclamation [regarding pneunomic influenza]. In Government Gazette of New South Wales; Ministry for Health and Medical Research: Sydney, Australia, 1919; pp. 781-782.

85. Anonymous. Border Traffic. Sydney Morning Herald, 8 February 1919; p. 13.

86. Eklund, E. The Dreaded Pneumonic Influenza Has Made Its Appearance Amongst Us: The Influenza Pandemic of 1918-1919 in Gippsland, Victoria. Aust. Hist. Stud. 2020, 52, 27-44. [CrossRef]

87. Curson, P.; McCracken, K. An Australian perspective of the 1918-1919 influenza pandemic. New South Wales Public Health Bull. 2006, 17, 103-107.

88. Moir, A. Into the West: The Movement of the Spanish Flu into the Far West New South Wales Border Towns and Beyond. Available online: https:/ / www.rahs.org.au/wp-content/uploads/2019/09/AlisonMoir-Hist141Sept2019.pdf (accessed on 31 December 2020).

89. Anonymous. The Influenza Menace. The Riverine Grazier, 4 March 1919; p.1.

90. Anonymous. Influenza Epidemic. Congestion on the Border. Herald, 7 February 1919; p. 7.

91. Anonymous. Influenza scare. Albury and Wodonga Infected. Alburt Banner, 7 February 1919; p. 44.

92. Anonymous. Border Quarantine. How to Cross the Murray. Examination at Albury. The Sun, 1 April $1919 ;$; p. 7.

93. Anonymous. Border Quarantine. Travellers Bocked at Union Bridge. Border Morning Mail, 7 May 1919; p. 3.

94. Anonymous. Trouble at the Border. Sydney Morning Herald, 19 April 1919; p. 12 col. d.

95. Anonymous. Border Troubles. Sydney Morning Herald, 11 February 1919; p. 7 col. h.

96. Anonymous. Murray Police Patrols. Border Morning Mail, 7 February 1919; p. 2.

97. Anonymous. On the Borders. Many Swim the Murray. Sydney Morning Herald, 7 February 1919; p. 8.

98. Gray, I. Maintaining the power of central governments: Regional land transport in the Australian Federation, 1850-2007. J. Transport. Hist. 2009, 30, 22-39. [CrossRef]

99. Joy, S. Unregulated Road Haulage: The Australian Experience. Oxf. Econ. Pap. 1964, 16, 275-285. [CrossRef]

100. Anonymous. Infantile Paralysis. Border Patrol Starts To-Day. Argus, 28 August 1937; p. 21.

101. Brooks, D. Proclamation. Prohibition of the bringing of certain fruits and vegetables into Victoria. In Victoria Government Gazette; Victorian Government: Melbourne, Australia, 1959; p. 1763.

102. Mahlstedt, A. Regulations under the Vegetation and Vine Diseases Act 1958. In Victoria Government Gazette; Victorian Government: Melbourne, Australia, 1959; pp. 1766-1767.

103. Munday, R. Albury-Wodonga. Growing fast but staying friendly. Australian Women's Weekly, 16 May $1979 ;$ pp. $40-41$.

104. Pennay, B. Making a City in the Country: The Albury-Wodonga National Growth Centre Project 1973-2003; UNSW Press: Sydney, Australia, 2005.

105. Stein, C. The Growth and Development of Albury-Wodonga 1972-2006: United and Divided; Macquarie University: Sydney, Australia, 2016.

106. Harris, C.P.; Dixon, K.E. Regional Planning in New South Wales and Victoria Since 1944 with Special Reference to the Albury-Wodonga Growth Centre; Centre for Research on Federal Financial Relations, Australian National University Press: Canberra, Australia, 1978.

107. Carver, S.R. Census of the Commonwealth of Australia 30th June, 1954. Volume II-Victoria. Part. I-Analysis of Population in Local Government Areas, etc.; Commonwealth Bureau of Census and Statistics: Canberra, Australia, 1954.

108. Bayley, W.A. Border City. History of Albury, New South Wales, 2nd ed.; Weston \& Co: Kiama, Australia, 1976.

109. Archer, K.M. Census of the Commonwealth of Australia 30th June, 1961. Volume II-Victoria. Part. I-Analysis of Population in Local Government Areas, etc.; Commonwealth Bureau of Census and Statistics: Canberra, Australia, 1961.

110. ABS. 3105.0.65.001 Australian Historical Population Statistics, 2019. 3. Population Distribution; Australian Bureau of Statistics: Canberra, Australia, 2019.

111. Archer, W.H. Population. In Statistical Register of Victoria for the Year 1861; John Ferres: Melbourne, Australia, 1862.

112. Archer, W.H. Population. In Statistics of The Colony of Victoria, for the Year 1871. Part. III. Population; John Ferres: Melbourne, Australia, 1872.

113. Hayter, H.H. Census of Victoria. In Statistical Register of Victoria for the Year 1891; John Ferres: Melbourne, Australia, 1881.

114. Hayter, H.H. Population. In Statistical Register of Victoria for the Year 1891; Robert S Brain: Melbourne, Australia, 1892.

115. ABS. 2001 Census QuickStats. All People, Location on Census Night. Australia. Local Government Areas Albury (C) (LGA10050); Australian Bureau of Statistics: Canberra, Australia, 2001.

116. ABS. 2001 Census QuickStats. All People, Location on Census Night. Australia. Local Government Areas Wodonga (RC) (LGA27170); Australian Bureau of Statistics: Canberra, Australia, 2001.

117. ABS. 2006 Census QuickStats. All People, Location on Census Night. Australia. Local Government Areas Albury (C) (LGA10050); Australian Bureau of Statistics: Canberra, Australia, 2006.

118. ABS. 2006 Census QuickStats. All People, Location on Census Night. Australia. Local Government Areas Wodonga (RC) (LGA27170); Australian Bureau of Statistics: Canberra, Australia, 2006.

119. Knibbs, G.H. Population. In Statistical Register of Victoria for the Year 1914; Albert J. Mullett: Melbourne, Australia, 1915. 
120. ABS. 2011 Census QuickStats. All People, Location on Census Night. Australia. Local Government Areas Albury (C) (LGA10050); Australian Bureau of Statistics: Canberra, Australia, 2011.

121. ABS. 2011 Census QuickStats. All People, Location on Census Night. Australia. Local Government Areas Wodonga (RC) (LGA27170); Australian Bureau of Statistics: Canberra, Australia, 2011.

122. Wickens, C.H. Census of the Commonwealth of Australia taken for the Night between the 3rd and 4th April, 1921. Part. XI. Victoria. Population of Local Government Areas; McCarron, Bird \& Co: Melbourne, Australia, 1925.

123. ABS. 2016 Census QuickStats. All People, Location on Census Night. Australia. Local Government Areas Albury (C) (LGA10050); Australian Bureau of Statistics: Canberra, Australia, 2016.

124. ABS. 2016 Census QuickStats. All People, Location on Census Night. Australia. Local Government Areas Wodonga (RC) (LGA27170); Australian Bureau of Statistics: Canberra, Australia, 2016.

125. Wilson, R. Census of the Commonwealth of Australia 30th June, 1947. Part. II-Analysis of Population in Local Government Areas. Victoria; L.F. Johnston: Canberra, Australia, 1947.

126. Anonymous. Extracts from the Border Anomalies Commitee. In Meeting the Challenges of the Border: Working Papers for A Conference Held on Friday 24 September 1999 at Charles Sturt University, Albury; Pennay, B., Ed.; Johnstone Centre, Charles Sturt University: Albury, Australia, 1999; pp. 11-30.

127. Ryan, G. Amalgamated Textiles became Macquarie Worsteds; Albury Historic Society: Albury, Australia, 1 August 2017.

128. Bubl, F.J. Borg-Warner at Albury-A case study in decentralisation. R. Aust. Plan. Inst. J. 1970, 8, 62-66. [CrossRef]

129. Jones, H.C. 10 Years of Hard Labour But DSI Still Ends in Tears. Available online: https: / www.bordermail.com.au/story/2320 340/10-years-of-hard-labour-but-dsi-still-ends-in-tears-opinion/ (accessed on 31 December 2020).

130. Crapp, G.; Gould, P. Cities of Albury and Wodonga Memorandum of Understanding on Co-operatiove Arrangements, June 1998. In Proceedings of the Challenges of the Border, Albury, Australia, 24 September 1999; Pennay, B., Ed.; Johnstone Centre, Charles Sturt University: Albury, Australia, 1999; pp. 31-33.

131. Mack, K.; Speedie, A. Two Cities One Community Partnership. In Agreement between the AlburyCIty and the City of Wodonga; 2017. Available online: https:/ / www.alburywodonga.gov.au/news/historic-agreement. (accessed on 31 December 2020).

132. AlburyCity; Wodonga, C.O. Two Cities One Community Action Plan. 2017-2021; AlburyCity \& City of Wodonga: Albury, Australia; Wodonga, Australia, 2017.

133. Murphy, C.; Sabesan, S.; Steer, C.; Yates, P.; Booms, A.; Jones, V.; Simpson, A.; Clarke, K.; Eek, R.; Ashley, D. Oncology service initiatives and research in regional Australia. Aust. J. Rural Health 2015, 23, 40-48. [CrossRef]

134. Melville, N. Cancer care across borders: The potential for excellence when collaboration is genuine. Cancer Forum 2007, 31, 81-84

135. McCormack, M.; Barilaro, J.; Symes, J.; Mack, K.; Speedie, A. Statement of Intent for the Albury Wodonga Regional Deal between the Commonwealth of Australia, State of New South Wales, State of Victoria, Albury City Council and Wodonga City Council. Available online: https:/ / minister.infrastructure.gov.au/mccormack/media-release/exciting-regional-deal-albury-wodonga (accessed on 31 December 2020).

136. Jones, E.; Jones, P.R.; Horsfall, W.; O’Dwyer, P. A Strategy For Rural Living: From the Albury-Wodonga Regional Planning Strategy. Aust. Plan. 1992, 30, 41-44. [CrossRef]

137. MHMR. Public Health (COVID-19 Restrictions on Gathering and Movement) Order 2020 (30 March 2020). In New South Wales Government Gazette; Ministry for Health and Medical Research: Sydney, Australia, 2020; pp. 1149-1163.

138. MHMR. Public Health (COVID-19 Restrictions on Gathering and Movement) Order (No. 2) 2020 (14 May 2020). In New South Wales Government Gazette; Ministry for Health and Medical Research: Sydney, Australia, 2020; pp. 2004-2020.

139. van Diemen, A. Public Health and Wellbeing Act 2008 Section 200. Directions from Deputy Chief Health Officer in accordance with emergency powers arising from declared state of emergency. Stay at Home Directions (No. 7). In Victoria Government Gazette; Victorian Government: Melbourne, Australia, 2020; Volume S253/2020, pp. 12-19.

140. van Diemen, A. Public Health and Wellbeing Act 2008 Section 200. Directions from Deputy Chief Health Officer in accordance with emergency powers arising from declared state of emergency. Stay at Home Directions (No. 2). In Victoria Government Gazette; Victorian Government: Melbourne, Australia, 2020; Volume S177/2020, pp. 1-7.

141. van Diemen, A. Public Health and Wellbeing Act 2008 Sections 190 and 200. Directions from Deputy Chief Health Officer in accordance with emergency powers arising from declared state of emergency. Restricted Activity Directions. In Victoria Government Gazette; Victorian Government: Melbourne, Australia, 2020; Volume S169/2020, pp. 1-7.

142. van Diemen, A. Public Health and Wellbeing Act 2008 Section 200. Directions from Deputy Chief Health Officer in accordance with emergency powers arising from declared state of emergency. Stay at Home Directions. In Victoria Government Gazette; Victorian Government: Melbourne, Australia, 2020; Volume S169/2020, pp. 8-13.

143. MHMR. Public Health (COVID-19 Border Control) Order 2020 (7 July 2020). In New South Wales Government Gazette; Ministry for Health and Medical Research: Sydney, Australia, 2020; pp. 3477-3485.

144. NSW Spatial Services. Public Health (COVID-19 Border Control) Border Zone Map PP5307; NSW Spatial Services: Sydney, Australia, 2020.

145. Whitsed, R. The NSW-Victoria Border Closure: Impacts on Workers and Alternative Scenarios-An Analysis of Census Data; Institute for Land, Water and Society Report Institute for Land, Water and Society, Charles Sturt University: Albury, Australia, 2020.

146. NSW Spatial Services. Public Health (COVID-19 Border Control) Border Zone Map PP5305-2; NSW Spatial Services: Sydney, Australia, 2020. 
147. NSW Spatial Services. Public Health (COVID-19 Border Control); Amendment Order; NSW Spatial Services: Sydney, Australia, 2020; pp. 3641-3653.

148. MHMR. Public Health (COVID-19 Border Control) Amendment (Border Community) Order 2020. In New South Wales Government Gazette; Ministry for Health and Medical Research: Sydney, Australia, 2020; pp. 3654-3657.

149. MHMR. Public Health (COVID-19 Border Control) Amendment (Vulnerable Persons) Order 2020. In New South Wales Government Gazette; Ministry for Health and Medical Research: Sydney, Australia, 2020; pp. 3801-3804.

150. MHMR. Public Health (COVID-19 Border Control) Amendment (Medical and Hospital Services) Order 2020. In New South Wales Government Gazette; Ministry for Health and Medical Research: Sydney, Australia, 2020; pp. 3805-3808.

151. MHMR. Public Health (COVID-19 Border Control) Amendment Order (No 2) 2020. In New South Wales Government Gazette; Ministry for Health and Medical Research: Sydney, Australia, 2020; pp. 4042-4052.

152. MHMR. Public Health (COVID-19 Border Control) Amendment (Transiting ACT Residents) Order 2020. In New South Wales Government Gazette; Ministry for Health and Medical Research: Sydney, Australia, 2020; pp. 4055-4059.

153. MHMR. Public Health (COVID-19 Border Control) Order 2020 Remote Communities Amendment (13 August 2020). In New South Wales Government Gazette; Ministry for Health and Medical Research: Sydney, Australia, 2020.

154. MHMR. Public Health (COVID-19 Border Control) Order 2020 School Exemption Amendment (20 August 2020). In New South Wales Government Gazette; Ministry for Health and Medical Research: Sydney, Australia, 2020.

155. MHMR. Public Health (COVID-19 Border Control) Amendment Order (No 3) 2020. In New South Wales Government Gazette; Ministry for Health and Medical Research: Sydney, Australia, 2020; pp. 4206-4210.

156. MHMR. Public Health (COVID-19 Border Control) Order 2020 (Flight Crew Exemption Amendment 4 September 2020). In New South Wales Government Gazette; Ministry for Health and Medical Research: Sydney, Australia, 2020.

157. MHMR. Public Health (COVID-19 Border Control) Amendment Order (No 4) 2020. In New South Wales Government Gazette; Ministry for Health and Medical Research: Sydney, Australia, 2020; pp. 5390-5393.

158. MHMR. Public Health (COVID-19 Border Control) Amendment Order (No 5) 2020. In New South Wales Government Gazette; Ministry for Health and Medical Research: Sydney, Australia, 2020.

159. MHMR. Public Health (COVID-19 Border Control) Amendment Order (No 6) 2020. In New South Wales Government Gazette; Ministry for Health and Medical Research: Sydney, Australia, 2020.

160. MHMR. Public Health (COVID-19 Border Control) Amendment Order (No 7) 2020. In New South Wales Government Gazette; Ministry for Health and Medical Research: Sydney, Australia, 2020.

161. MHMR. Public Health (COVID-19 Border Control) Amendment Order (No 8) 2020. In New South Wales Government Gazette; Ministry for Health and Medical Research: Sydney, Australia, 2020.

162. MHMR. Public Health (COVID-19 Border Control) Order (No 2). In New South Wales Government Gazette; Ministry for Health and Medical Research: Sydney, Australia, 2020.

163. MHMR. Public Health (COVID-19 Border Control) (No 2) Order Amendment Order 2020. In New South Wales Government Gazette; Ministry for Health and Medical Research: Sydney, Australia, 2020.

164. MHMR. Public Health (COVID-19 Border Control) Order (No 2) Repeal Order 2020. In New South Wales Government Gazette; Ministry for Health and Medical Research: Sydney, Australia, 2020.

165. McMillan, A. 'Appalling': Melbourne Person Fined after Driving 320 km for a Big Mac. Available online: https: / news.ebenemagazine.com/appalling-melbourne-person-fined-after-driving-320km-for-a-big-mac/ (accessed on 31 December 2020).

166. Victoria Health and Human Services. Premier's Statement on Changes to Regional Restrictions; Victoria Health and Human Services: Melbourne, Australia, 2020.

167. Victoria Health and Human Services. Premier's Statement on Changes to Melbourne's Restrictions; Victoria Health and Human Services: Melbourne, Australia, 2020.

168. NSW Spatial Services. Public Health (COVID-19 Border Control) Map (No.2) PP5305-4-1; NSW Spatial Services: Sydney, Australia, 2020.

169. Keoghan, S. Woman tries to cross into NSW from Victoria in car boot. Sydney Morning Herald, 6 September 2020.

170. Anonymous. Coronavirus: Woman cops $\$ 2000$ in Fines for Sneaky Border Crossing Attempt. Available online: https: / / www.adelaidenow.com.au/news/national/coronavirus-woman-cops-2000-in-fines-for-sneaky-border-crossing-attempt/ news-story /4170437c8167fd71d43dd465c03b991c (accessed on 31 December 2020).

171. NSW Spatial Services. Public Health and Medical Research: Sydney, Australia(COVID-19 Border Control) Map (No.5) PP5305-7; NSW Spatial Services: Sydney, Australia, 2020.

172. Spennemann, D.H.R. Collecting COVID-19 Ephemera: A photographic Documentation of Examples from Regional Australia; Institute for Land, Water and Society Report Institute for Land, Water and Society, Charles Sturt University: Albury, Australia, 2021.

173. Sutton, B. Public Health and Wellbeing Act 2008 Section 200. Directions from Chief Health Officer in accordance with emergency powers arising from declared state of emergency. New South Wales Border Crossing Permit Scheme Directions. In Victoria Government Gazette; Victorian Government: Melbourne, Australia, 2020; Volume S679/2020, pp. 1-16.

174. Looker, C. Public Health and Wellbeing Act 2008 Section 200. Directions from Deputy Chief Health Officer in accordance with emergency powers arising from declared state of emergency. New South Wales and Queensland Border Crossing Scheme Directions (No. 3). In Victoria Government Gazette; Victorian Government: Melbourne, Australia, 2020; Volume S701/2020, pp. 1-12. 
175. Spennemann, D.H.R. COVID-19 on the ground: Heritage sites of a pandemic. Heritage, submitted.

176. Sutton, B. Public Health and Wellbeing Act 2008 Section 200. Directions from Chief Health Officer in accordance with emergency powers arising from declared state of emergency. Victorian Border Crossing Permit Directions (No. 5). In Victoria Government Gazette; Victoria Government Gazette: Melbourne, Australia, 2021; Volume S47/2020, pp. 2-35.

177. Victoria State Government. Information for Cross Border Communities. Advice about Communities that Share a Border with Victoria (Border Communities). Available online: https://www.coronavirus.vic.gov.au/information-cross-border-communities (accessed on 15 February 2021).

178. Sutton, B. Public Health and Wellbeing Act 2008 Section 200. Directions from Chief Health Officer in accordance with emergency powers arising from declared state of emergency. New South Wales Border Crossing Permit Scheme Directions (No. 2). In Victoria Government Gazette; Victoria Government Gazette: Melbourne, Australia, 2020; Volume S681/2020.

179. Looker, C. Public Health and Wellbeing Act 2008 Section 200. Directions from Deputy Chief Health Officer in accordance with emergency powers arising from declared state of emergency. New South Wales Border Crossing Permit Scheme Directions (No. 4). In Victoria Government Gazette; Victoria Government Gazette: Melbourne, Australia, 2021; Volume S1/2021, pp. $22-31$.

180. Looker, C. Public Health and Wellbeing Act 2008 Section 200. Directions from Deputy Chief Health Officer in accordance with emergency powers arising from declared state of emergency. New South Wales Border Crossing Permit Scheme Directions (No. 5). In Victoria Government Gazette; Victoria Government Gazette: Melbourne, Australia, 2021; Volume S2/2021, pp. 1-12.

181. Looker, C. Public Health and Wellbeing Act 2008 Section 200. Directions from Deputy Chief Health Officer in accordance with emergency powers arising from declared state of emergency. New South Wales Border Crossing Permit Scheme Directions (No. 6). In Victoria Government Gazette; Victoria Government Gazette: Melbourne, Australia, 2021; Volume S3/2021, pp. 81-93.

182. Crouch, S. Public Health and Wellbeing Act 2008 Section 200. Directions from Deputy Chief Health Officer in accordance with emergency powers arising from declared state of emergency. New South Wales Border Crossing Permit Scheme Directions (No. 7). In Victoria Government Gazette; Victoria Government Gazette: Melbourne, Australia, 2021; Volume S11/2021, pp. 1-16.

183. Cheng, A. Public Health and Wellbeing Act 2008 Section 200. Directions from Acting Chief Health Officer in accordance with emergency powers arising from declared state of emergency. New South Wales Border Crossing Permit Scheme Directions (No. 8). In Victoria Government Gazette; Victoria Government Gazette: Melbourne, Australia, 2021; Volume S14/2021, pp. 1-20.

184. Looker, C. Public Health and Wellbeing Act 2008 Section 200. Directions from Deputy Chief Health Officer in accordance with emergency powers arising from declared state of emergency. New South Wales and Queensland Border Crossing Scheme Directions. In Victoria Government Gazette; Victoria Government Gazette: Melbourne, Australia, 2021; Volume S15/2021, pp. 1-20.

185. Sutton, B. Public Health and Wellbeing Act 2008 Section 200. Directions from Chief Health Officer in accordance with emergency powers arising from declared state of emergency. Victorian Border Crossing Permit Directions. In Victoria Government Gazette; Victoria Government Gazette: Melbourne, Australia, 2021; Volume S20/2021, pp. 1-60.

186. Sutton, B. Public Health and Wellbeing Act 2008 Section 200. Directions from Chief Health Officer in accordance with emergency powers arising from declared state of emergency. Victorian Border Crossing Permit Directions (No. 2). In Victoria Government Gazette; Victoria Government Gazette: Melbourne, Australia, 2021; Volume S23/2021, pp. 1-28.

187. Sutton, B. Public Health and Wellbeing Act 2008 Section 200. Directions from Chief Health Officer in accordance with emergency powers arising from declared state of emergency. Victorian Border Crossing Permit Directions (No. 3). In Victoria Government Gazette; Victoria Government Gazette: Melbourne, Australia, 2021; Volume S1/2021.

188. Sutton, B. Public Health and Wellbeing Act 2008 Section 200. Directions from Chief Health Officer in accordance with emergency powers arising from declared state of emergency. Victorian Border Crossing Permit Directions (No. 4). In Victoria Government Gazette; Victoria Government Gazette: Melbourne, Australia, 2020; Volume S38/2021, pp. 1-48.

189. Sutton, B. Public Health and Wellbeing Act 2008 Section 200. Directions from Chief Health Officer in accordance with emergency powers arising from declared state of emergency. Stay Safe Directions (Victoria) (No. 14). In Victoria Government Gazette; Victoria Government Gazette: Melbourne, Australia, 2021; Volume S70/2021, pp. 1-15.

190. Sutton, B. Public Health and Wellbeing Act 2008 Section 200. Directions from Chief Health Officer in accordance with emergency powers arising from declared state of emergency. Restricted Activity Directions (Victoria) (No. 7). In Victoria Government Gazette; Victoria Government Gazette: Melbourne, Australia, 2021; Volume S70/2021, pp. 16-22.

191. Howie, J. Albury High School Limits Classes In Lockdown as Victorian Staff Barred. Border Mail, 14 February $2021 ;$ p. 6.

192. Jones, V. Victorian Staff, Students Banned in NSW. Border Mail, 15 February 2021; p. 7.

193. Whitsed, R. Why the $5 \mathrm{~km}$ Rule Makes No Sense in Regional Victoria. Available online: https://thinkspace.csu.edu.au/ morethanmaps /2021/02/15/why-the-5km-rule-makes-no-sense-in-regional-victoria/ (accessed on 16 February 2021).

194. Neuwirth, L.S.; Jović, S.; Mukherji, B.R. Reimagining higher education during and post-COVID-19: Challenges and opportunities. J. Adult Contin. Educ. 2020. [CrossRef]

195. Kramer, A.; Kramer, K.Z. The potential impact of the Covid-19 pandemic on occupational status, work from home, and occupational mobility. J. Vocat. Behav. 2020, 119, 103442. [CrossRef] [PubMed]

196. Spennemann, D.H.R. Residential Architecture in a post-pandemic world: Implications of COVID-19 for new construction and for adapting heritage buildings. J. Green Build. 2021, 16, 199-215. [CrossRef]

197. Musselwhite, C.; Avineri, E.; Susilo, Y. Editorial JTH 16-The Coronavirus Disease COVID-19 and implications for transport and health. J. Transp. Health 2020, 16, 100853. [CrossRef] [PubMed] 
198. Ye, Z.-W.; Yuan, S.; Yuen, K.-S.; Fung, S.-Y.; Chan, C.-P.; Jin, D.-Y. Zoonotic origins of human coronaviruses. Int. J. Biol. Sci. 2020, 16, 1686. [CrossRef] [PubMed]

199. Wang, L.-F.; Anderson, D.E.; Mackenzie, J.S.; Merson, M.H. From Hendra to Wuhan: What has been learned in responding to emerging zoonotic viruses. Lancet 2020, 395, e33-e34. [CrossRef] 